\title{
Evaluation of bioprinter technologies
}

\author{
Ibrahim T. Ozbolat ${ }^{\text {a,b,c, d,1 }}$, Kazim K. Moncal ${ }^{\text {a,b }}$, Hemanth Gudapati ${ }^{\text {a,b }}$ \\ ${ }^{a}$ Engineering Science and Mechanics Department, The Pennsylvania State University, State College, PA, 16802 \\ ${ }^{\mathrm{b}}$ The Huck Institutes of the Life Sciences, The Pennsylvania State University, State College, PA, 16802 \\ ${ }^{c}$ Materials Research Institute, The Pennsylvania State University, State College, PA, 16802 \\ ${ }^{\mathrm{d}}$ Biomedical Engineering, The Pennsylvania State University, State College, PA, 16802
}

\begin{abstract}
Since the first printing of biologics with cytoscribing as demonstrated by Klebe in 1986, three dimensional (3D) bioprinting has made a substantial leap forward, particularly in the last decade. It has been widely used in fabrication of living tissues for various application areas such as tissue engineering and regenerative medicine research, transplantation and clinics, pharmaceutics and high-throughput screening, and cancer research. As bioprinting has gained interest in the medical and pharmaceutical communities, the demand for bioprinters has risen substantially. A myriad of bioprinters have been developed at research institutions worldwide and several companies have emerged to commercialize advanced bioprinter technologies. This paper prefaces the evolution of the field of bioprinting and presents the first comprehensive review of existing bioprinter technologies. Here, a comparative evaluation is performed for bioprinters; limitations with the current bioprinter technologies are discussed thoroughly and future prospects of bioprinters are provided to the reader.
\end{abstract}

Keywords: Bioprinting, Bioprinting Technologies, Bioprinters, Tissue and Organ Fabrication

\section{From 3D Printing to Bioprinting}

Three dimensional (3D) printing has opened a revolutionary era in medical product design and development and is widely used in fabrication of custom-made anatomically-correct tissue scaffolds, where biomaterials are deposited through a computer-controlled dispensing system to specific points in

\footnotetext{
${ }^{1}$ Corresponding author: email: ito1@ @su.edu, phone: (814)8635819
} 
3D space. [1,2]. Three-dimensional printing is preferred when building engineered tissue structures due to its repeatability and high accuracy in micro-scales [3]. Various 3D printing techniques such as material extrusion, powder bed fusion [4,5], binder jetting [6] and vat photopolymerization [7] have been used to fabricate biologically inert tissue constructs by replacing non-medical grade materials with biocompatible and bioresorbable materials such as synthetic and natural polymers [8], natural and inorganic ceramic materials $[9,10]$, or recently developed biodegradable metals [11]. Adaptation of 3D printing into tissue engineering brings unique capabilities in rapid fabrication of tissue scaffolds with controlled porosity and internal architecture, tunable mechanical and structural properties, and the ability to load drug or protein molecules for enhanced cellular response and customized/multifunctional characteristics, which can guide the cellular environment for enhanced tissue regeneration.

Despite its potential benefits in biofabrication of anatomically correct tissue scaffolds, 3D printing of inert materials in tissue engineering faces several limitations in the generation of complex tissues and organs for transplantation or other uses [12]. First of all, manually driven cell placement on the scaffold micro-architecture lacks the necessary precision. It is highly challenging to manually seed, place and pattern cells to recapitulate the complex configurations of various cell types in natural tissues and organs. In addition, seeding cells in high cell density is not trivial because cells can only attach to the scaffold surface and cannot penetrate into the matrix. Scaffold biomaterial also occupies a significant volume of space, which does not allow cells to expand to sufficient numbers. In addition, the need for vascularization is essential to develop thick tissues and organs with an efficient exchange of media to keep the cells oxygenated, viable and functional; however, creation of such a network is challenging using conventional 3D printing technologies [2]. These difficulties have led many researchers toward the development of 3D bioprinting technologies, where cells are encapsulated at high density, and printed and patterned into desired shapes to facilitate heterocellular interactions that are present in native tissues and organs [13-15].

Bioprinting was first demonstrated by Klebe in 1988 as cytoscribing technology, a method of micro-positioning biologics including collagen and fibronectin [16]. In that study, cytoscribing was 
carried out using a Hewlett Packard (HP) inkjet printer and a graphics plotter for specific positioning of cells. In 1999, cells were bioprinted with a laser-based bioprinting process by Odde and Renn [17], demonstrating that cells could be patterned in 3D to biomimetically develop tissue analogues with complex anatomy. In 2003, Boland and his coworkers started inkjet-based bioprinting by modifying an HP inkjet printer, and cells were successfully bioprinted and patterned [18]. Several researchers then attempted 3D printing of tissue scaffolds using extrusion-based techniques with and without cells [19,20]. With the establishment of the first manufacturing institute (the National Additive Manufacturing Innovation Institute) in the United States (US) in the area of 3D printing and additive manufacturing, use of 3D printing in biological research has escalated; enormous progress has been made in the last four years, which has positively affected bioprinting technology and research [21]. Since then, several spin-off companies have emerged to commercialize breakthrough technologies worldwide. Recent approaches in hybrid vascularized tissue printing with next-generation bioprinters [22] will push the technology even further to create scale-up tissues, tissues of clinically relevant sizes, and ultimately whole organ printing.

In this review, bioprinter technologies are presented under three major bioprinting modalities including extrusion-, droplet- and laser-based bioprinting, and a comparative evaluation is performed for commercial use bioprinters. Limitations with the current bioprinter technologies are discussed and future prospects of bioprinters are provided to the reader.

\section{Bioprinter Technologies}

According to their bioprinting modality, bioprinters can be classified under three main groups including extrusion-, droplet- and laser-based bioprinters. Extrusion-based bioprinters use mechanical- or pneumatic-driven system that deposit cells in the form of a filament, whereas droplet-based bioprinters utilize thermal-, piezo- or acoustic-driven mechanisms to deposit droplets of cell suspension in a highthroughput manner. Laser-based bioprinters, on the other hand, utilize laser energy to deposit cells from a donor slide to a receiver slide without the need for a nozzle [2]. A detailed comparison of bioprinting modalities was presented in our earlier work [14] and the reader is referred to these studies for more information regarding strengths and weaknesses of each technology. 
As the field of bioprinting has evolved into its current state, a wide variety of bioprinters have been created by research groups around the globe in addition to development of commercial bioprinters by a number of companies [23]. According to a recent work [14], the ideal bioprinter should possess the following capabilities:

- High degree-of-freedom in motion that allows deposition of the bioink solution on non-planar surfaces. This is crucial as bioprinters transition into clinical applications and are used to bioprint cells into a biological lesion site.

- High resolution and accuracy that enable deposition of bioink solutions with sufficient fidelity to simulate cell placement in native tissues.

- High speed motion that enables rapid fabrication of human-scale tissue and organ constructs for clinical transplantation as well as high-throughput production of tissue models for pharmaceutics and cancer research [24].

- The ability to dispense various bioink solutions simultaneously to facilitate fabrication of heterocellular tissues closely mimicking native tissues.

- Ease of use that allows operators, with minimum skills and experience, to operate the bioprinter.

- Compact size that allows placement under a standard biosafety or a laminar flow hood for bioprinting in sterile conditions.

- Ease of sterilization that allows operators to readily sterilize and maintain aseptic conditions during a bioprinting process.

- Full-automation capability that facilitates bioprinting of tissue and organ constructs without user intervention.

- Affordability that allows researchers to acquire instrumentation and explore new investigative areas. 
- Versatility that allows operators to modify and expand the instrumentation for multi-purpose use.

Not all of the bioprinters possess the aforementioned-capabilities and a majority of bioprinters are designed for basic research use only. Figure 1 depicts a representative bioprinting system [22] along with its components. In a typical bioprinting process, computer-aided design (CAD) software is required to generate the toolpath plan [25] for automated motion and dispensing systems. The motion system provides the movement to the bioprinter in $x^{-}, y_{-}$, and z-axes and the dispensing system (pneumatic-, mechanical- or fluidic-driven) controls the accurate deposition of the bioink (the bioprintable material used in bioprinting process) through the bioprinter head. The system presented in Figure 1 is an extrusionbased bioprinting (EBB) system, which is the most common bioprinting modality. Other bioprinting modalities, such as droplet- and laser-based bioprinting, may, however, exhibit different system configurations. This section discusses bioprinter technologies under three main bioprinting modalities: extrusion-, droplet- and laser-based bioprinting.

\subsection{Extrusion-based Bioprinters}

Extrusion-based bioprinting is the most common modality used in bioprinting research due to its practicality and ability to fabricate larger-scale $3 \mathrm{D}$ constructs $[14,26]$. In $\mathrm{EBB}$, the bioink solution is extruded through a micro-nozzle tip and written in the form of cylindrical filaments to lay down 3D tissue constructs [27-32]. Extrusion-based bioprinting was first demonstrated by researchers at Freiburg Materials Research Center in the early 2000s [33], then commercialized by EnvisionTec as 3DBioplotter®. Since then, a number of extrusion-based bioprinters have been devised by a number of companies. Commercially available extrusion-based bioprinters, summarized in Table 1, are grouped into five categories including (i) conventional extrusion-based bioprinters, (ii) extrusion-based bioprinters with higher degrees of motion freedom, (iii) extrusion-based bioprinters supporting bioplotting process, (iv) extrusion-based bioprinters supporting bioprinting of cell aggregates and (v) extrusion-based bioprinters supporting other bioprinting modalities. 
Table 1. Commercially available extrusion-based bioprinters

\begin{tabular}{|c|c|c|c|c|c|c|c|c|c|}
\hline & & $\begin{array}{l}\text { Bioprinter } \\
\text { Name }\end{array}$ & Country & $\begin{array}{c}\text { Extrusion } \\
\text { Mechanism }\end{array}$ & Company & Use & $\begin{array}{l}\text { Dual Bioink } \\
\text { Printability }\end{array}$ & Features & $\begin{array}{c}\text { Year of } \\
\text { Market } \\
\text { Introduction }\end{array}$ \\
\hline \multirow{7}{*}{ 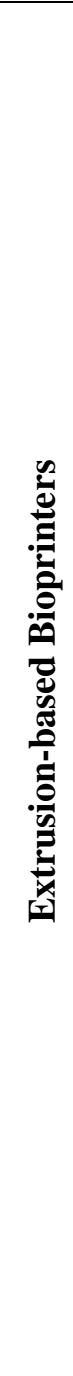 } & \multirow{7}{*}{ 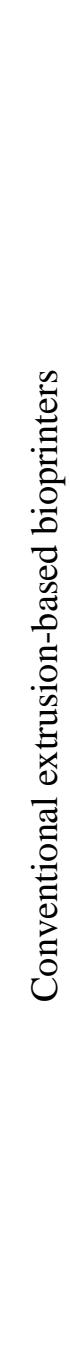 } & $\begin{array}{l}\text { The Alpha } \\
\text { Bioprinter }\end{array}$ & UK & $\begin{array}{l}\text { Pneumatic } \\
\text { extrusion }\end{array}$ & $\begin{array}{c}\text { 3Dynamic } \\
\text { Systems } \\
(3 \mathrm{DS}) \\
\end{array}$ & NI & - & $\begin{array}{l}\text { Accuracy } \pm 75 \mu \mathrm{m} \mathrm{[34]} \\
\text { price: } \$ 12,400^{\S, *}\end{array}$ & $2013^{¥}$ \\
\hline & & $\begin{array}{l}\text { The Omega } \\
\text { Bioprinter }\end{array}$ & UK & $\begin{array}{l}\text { Pneumatic } \\
\text { extrusion }\end{array}$ & $\begin{array}{c}\text { 3Dynamic } \\
\text { Systems } \\
\text { (3DS) }\end{array}$ & NI & + & $\begin{array}{l}\text { Accuracy } \pm 50 \mu \mathrm{m}[35] \\
\text { price: } \$ 18,930^{\$, *}\end{array}$ & $2014^{¥}$ \\
\hline & & BioBot 1 & USA & $\begin{array}{l}\text { Pneumatic } \\
\text { micro- } \\
\text { extrusion }\end{array}$ & Biobots & $\begin{array}{l}\text { GelMA hydrogel } \\
\text { extrusion } \\
\text { optimization [36] }\end{array}$ & + & $\begin{array}{l}\text { Printing resolution: } 100 \mu \mathrm{m} \\
\text { [37] } \\
\text { Position precision: } 5.5 \mu \mathrm{m} \\
(\mathrm{x}-\mathrm{y} \text { axis) })^{¥}, 5 \mu \mathrm{m} \\
(\mathrm{z} \text { axes })^{¥} \text {, price: } \$ 10,000 \\
\text { [37] }\end{array}$ & $2015^{¥}$ \\
\hline & & Fab@Home & USA & $\begin{array}{l}\text { Mechanical } \\
\text { micro- } \\
\text { extrusion }\end{array}$ & $\begin{array}{l}\text { Seraph } \\
\text { Robotics }\end{array}$ & $\begin{array}{l}\text { Aortic valves } \\
\text { (porcine aortic valve } \\
\text { interstitial cells, } \\
\text { human aortic root } \\
\text { smooth muscle } \\
\text { cells) [38], filling } \\
\text { chondral and } \\
\text { osteochondral } \\
\text { defects [39], and ear } \\
\text { (chondrocytes) [40] }\end{array}$ & + & $\begin{array}{l}\text { Positioning resolution: } 15.8 \\
\mu \mathrm{m} \text { per full step, a nominal } \\
\text { top speed of } 25 \mathrm{~mm} / \mathrm{s}(\mathrm{x}-\mathrm{y}- \\
\mathrm{z} \text { axes })[41]\end{array}$ & $2006[41]$ \\
\hline & & $\begin{array}{l}\text { Fab@Home } \\
\text { MD4 }\end{array}$ & USA & $\begin{array}{l}\text { Pneumatic } \\
\text { extrusion }\end{array}$ & $\begin{array}{c}\text { Seraph } \\
\text { Robotics }\end{array}$ & $\mathrm{NI}$ & + & $50 \mu \mathrm{m}$ Gantry [42] & $2016^{¥}$ \\
\hline & & $\begin{array}{c}\text { Scientist 3D } \\
\text { printer }\end{array}$ & USA & $\begin{array}{l}\text { Pneumatic } \\
\text { extrusion }\end{array}$ & $\begin{array}{l}\text { Seraph } \\
\text { Robotics }\end{array}$ & NI & + & 5-10 $\mu \mathrm{m}$ Gantry [42] & N/A \\
\hline & & Inkredible & USA & $\begin{array}{l}\text { Micro- } \\
\text { extrusion }\end{array}$ & Cellink & NI & + & $\begin{array}{c}\text { x-y resolution per } \\
\text { microstep: } 10 \mu \mathrm{m} \\
\text { z resolution per microstep: } \\
\quad 2.5 \mu \mathrm{m} \\
\text { Layer resolution: } 50-100\end{array}$ & $2015^{¥}$ \\
\hline
\end{tabular}




\begin{tabular}{|c|c|c|c|c|c|c|c|c|}
\hline & & & & & & & $\begin{array}{c}\mu \mathrm{m}[43] \\
\text { Price: } \$ 5,000^{\S} \text { (Inkredible) } \\
\text { Price: } \$ 10,000^{\S} \\
\text { (Inkredible+) }\end{array}$ & \\
\hline & Regenovo & China & Extrusion & $\begin{array}{l}\text { Regonovo } \\
\text { Biotechnology } \\
\text { Co., Ltd. }\end{array}$ & $\begin{array}{c}\beta \text {-TCP bone scaffold } \\
\text { (mouse } \\
\text { mesenchymal } \\
\text { stromal cells) [44], } \\
\text { 3D gelatin/alginate } \\
\text { scaffolds [45] }\end{array}$ & + & Resolution $20 \mu \mathrm{m}[46]$ & $2013[63]$ \\
\hline & $\begin{array}{c}\text { Regemat 3D } \\
\mathrm{V}^{1}\end{array}$ & Spain & $\begin{array}{l}\text { Pneumatic } \\
\text { extrusion }\end{array}$ & Regemat 3D & $\mathrm{NI}$ & + & $\begin{array}{l}\text { Axis Resolution: } 150 \mu \mathrm{m}(\mathrm{x}- \\
\mathrm{y} \text { axis), } 400 \mathrm{~nm}(\mathrm{z}-\mathrm{axis}) \\
{[47], \text { price } \$ 13,250^{\$, \#}}\end{array}$ & $2015^{¥}$ \\
\hline 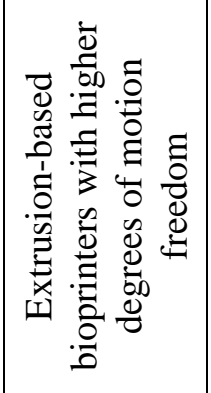 & $\begin{array}{l}\text { BioAssembly } \\
\text { Bot }\end{array}$ & USA & $\begin{array}{l}\text { Pneumatic } \\
\text { micro- } \\
\text { extrusion }\end{array}$ & $\begin{array}{l}\text { Advanced } \\
\text { solutions }\end{array}$ & Human Heart [23] & + & $\begin{array}{l}\text { Repeatedly up to } 20 \mu \mathrm{m} \\
{[48], \text { price }>\$ 159,995[48]}\end{array}$ & $2014^{¥}$ \\
\hline 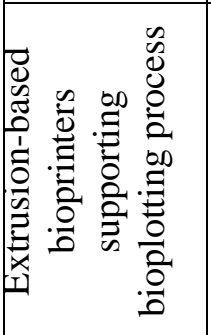 & 3D-BioPlotter & Germany & $\begin{array}{l}\text { Pneumatic } \\
\text { micro- } \\
\text { extrusion }\end{array}$ & EnvisionTec & $\begin{array}{l}\text { Bone (bone marrow } \\
\text { stromal cells) [49], } \\
\text { acellular } \\
\text { scaffolds) [50] }\end{array}$ & + & $\begin{array}{l}\text { Axis resolution: } 1 \mu \mathrm{m}(\mathrm{x}-\mathrm{y}- \\
\mathrm{z} \text { axis })[51] \\
\text { Speed: } 0.1-150 \mathrm{~mm} / \mathrm{s} \\
{[51], \text { price }>\$ 145,000^{\S}}\end{array}$ & $2003^{¥}$ \\
\hline 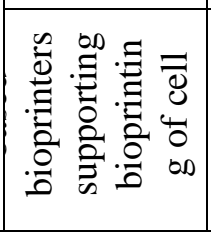 & $\begin{array}{l}\text { Novogen } \\
\text { MMX }^{\mathrm{TM}}\end{array}$ & USA & $\begin{array}{l}\text { Mechanical } \\
\text { micro- } \\
\text { extrusion }\end{array}$ & Organovo & $\begin{array}{l}\text { Bone [52], liver } \\
\text { (human hepatocytes, } \\
\text { hepatic satellite cells } \\
\text { and endothelial } \\
\text { cells) [53], breast }\end{array}$ & + & Precision: $20 \mu \mathrm{m}$ [23] & 2009 [23] \\
\hline
\end{tabular}




\begin{tabular}{|c|c|c|c|c|c|c|c|c|}
\hline & & & & & $\begin{array}{c}\text { cancer (MSC } \\
\text { differentiated } \\
\text { adipose cells, } \\
\text { mammary } \\
\text { fibroblasts and } \\
\text { endothelial cells) } \\
\text { [54], vascularization } \\
\text { (calvarial pre- } \\
\text { osteoblasts cells and } \\
\text { human umbilical } \\
\text { vein endothelial } \\
\text { cells) [55] }\end{array}$ & & & \\
\hline & nScrypt & USA & $\begin{array}{l}\text { Pneumatic } \\
\text { micro- } \\
\text { extrusion }\end{array}$ & $\begin{array}{l}\text { Sciperio/nScry } \\
\text { pt }\end{array}$ & $\begin{array}{l}\text { Vascularization and } \\
\text { skin (human primary } \\
\text { fibroblasts, bovine } \\
\text { aortic endothelial } \\
\text { cells) [56] }\end{array}$ & + & $\begin{array}{l}\text { Price range: } \$ 200,000 \text { - } \\
\$ 400,000[23]\end{array}$ & 2002 [23] \\
\hline \multirow{4}{*}{ 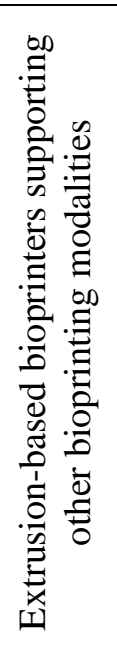 } & Bio3D SYN^ $^{\wedge}$ & Singapore & $\begin{array}{l}\text { Micro- } \\
\text { extrusion }\end{array}$ & $\begin{array}{c}\text { Bio3D } \\
\text { technologies }\end{array}$ & NI & + & $\begin{array}{c}1 \mu \mathrm{m}(\mathrm{x}-\mathrm{y}-\mathrm{z} \text { resolution }) \\
{[57]} \\
\text { Speed: } 10-300,000 \\
\mu \mathrm{m} / \mathrm{min}[57]\end{array}$ & N/A \\
\hline & $\begin{array}{l}\text { Bio3D } \\
\text { Explorer }\end{array}$ & Singapore & $\begin{array}{l}\text { Micro- } \\
\text { extrusion }\end{array}$ & $\begin{array}{c}\text { Bio3D } \\
\text { technologies }\end{array}$ & NI & + & $\begin{array}{c}5 \mu \mathrm{m}(\mathrm{x}-\mathrm{y}-\mathrm{z} \text { resolution }) \\
{[57]}\end{array}$ & N/A \\
\hline & 3D Discovery & Switzerland & $\begin{array}{l}\text { Pneumatic } \\
\text { micro- } \\
\text { extrusion }\end{array}$ & RegenHU & $\begin{array}{l}\text { Cartilage (human } \\
\text { chondrocytes) [58] }\end{array}$ & + & $\begin{array}{c}\text { Printing materials up to } \\
\text { viscosity } 10,000 \mathrm{mPa}-\mathrm{S} \\
{[23]}\end{array}$ & 2012 [23] \\
\hline & BioFactory & Switzerland & $\begin{array}{l}\text { Pneumatic } \\
\text { micro- } \\
\text { extrusion }\end{array}$ & RegenHU & $\begin{array}{c}\text { Air-blood tissue } \\
\text { barrier (human } \\
\text { alveolar epithelial } \\
\text { type } 2 \text { and HUVEC) } \\
{[59]}\end{array}$ & + & $\begin{array}{l}\text { Printing resolution: }<5 \mu \mathrm{m} \\
{[59]}\end{array}$ & 2012 [23] \\
\hline
\end{tabular}

NI - No published research article has been identified.

N/A - Information not available.

+ Capable of bioprinting one or more bioink at a time.

- Capable of bioprinting only one bioink at a time. 
$\S$ Pricing information has been obtained from the company.

¥ Information has been obtained from the company.

* Prices were converted from British Pound to US Dollar on August 19, 2016 and are subjected to change depending on the exchange rate.

\# Prices were converted from Euro to US Dollar on August 19, 2016 and are subjected to change depending on the exchange rate. 


\subsubsection{Conventional extrusion-based bioprinters}

Alpha and Omega Bioprinters. 3Dynamic Systems from The United Kingdom (UK) has introduced their commercially available 3D bioprinting systems, Alpha and Omega Bioprinters [60]. The company has spun off from Swansea University in the UK and both bioprinter models have been used to develop human tissue constructs. The Alpha bioprinter (see Figure 2A) has a single extrusion printhead that is able to bioprint a wide range of biomaterials. It has an induction heating system available for thermosensitive biomaterials. The Omega bioprinter, on the other hand, possesses extended capabilities compared to that of the Alpha bioprinter. As shown in Figure 2B, Omega series has a dual-extruder printhead with an optional resistance heating system enabling hybrid bioprinting of tissue constructs. The size and work envelope of the Omega bioprinter is larger than that of the Alpha bioprinter. Both bioprinters were designed with a high degree of precision enabling accurate deposition control for bioprinting of anatomically-correct, patient-specific scaffolds. The Alpha bioprinter was designed specifically to print bone tissue scaffolds for regenerative medicine and the Omega bioprinter was designed to bioprint soft living tissue structures using bioactive gels, proteins and hydrogels [35].

Biobot. Biobots has recently launched in the US to introduce a versatile, extrusion-based bioprinter as an economical alternative to the more expensive bioprinters. The first version was marketed in 2014 with a single-nozzle dispensing capability; it has been recently upgraded to a dual-nozzle head version that can bioprint both thermo-sensitive (with maximum temperature of $100{ }^{\circ} \mathrm{C}$ ) and photocrosslinkable (LED range of 405-410 nm) hydrogels [37]. The newest version of their bioprinter, Biobot 1, is shown in Figure 2C. The bioprinter is highly compact occupying just a cubic foot of space. It is significantly smaller than other commercially available bioprinters and can easily fit into a standard biosafety cabinet.

Fab@Home. In 2006, as a result of the Fab@Home project at Cornell University in the US, researchers released a low cost, versatile open-source 3D printer [41]. Since then, thousands of 3D printers were built across the world, inspiring several ventures into the construction of open-source 3D printers. The Fab@Home printer is equipped with multiple print-heads loaded with mechanical extruders 
and has been used in multi-material printing such as food and living cells. Fab@Home bioprinters are currently commercialized by Seraph Robotics in the US and have been utilized by various research and academic institutions [42]. Fab@Home bioprinters, including Fab@Home M3, Scientist and Fab@Home M4 models, have been utilized to bioprint tissue constructs including, but not limited to, cartilage [61], bone [39] and heart valve [62].

Inkredible. Cellink is a recently established company in the US commercializing their first bioprinter "Inkredible [43]." The Inkredible, as shown Figure 2D, has a printhead with a dual-extruder for bioprinting hydrogel solutions and can easily fit in a standard biosafety cabinet allowing operation under sterile conditions. The company also introduced "Inkredible+" model, which possesses a digitally controlled heating unit (with temperature range of $25-85^{\circ} \mathrm{C}$ ), pneumatic actuated dual-extruder heads, and a flow unit in its enclosure for sterilization purposes. The size and work envelope of the Inkredible+ bioprinter is larger than that of the Inkredible bioprinter; however, both bioprinters have an ultra-violet (UV) lamp for photocurable hydrogels and are operated with Repetier-Host software, which runs G-code.

Regenovo. In another location, researchers from Hangzhou Dianzi University in China announced the invention of the first 3D bioprinter with independent intellectual property rights in China in 2013 [63]. The bioprinter, named Regenovo Bio-printer ${ }^{\mathrm{TM}}$ (with models including Bio-Printer ${ }^{\mathrm{TM}}-$ Lite, Bio-Printer ${ }^{\mathrm{TM}}$-Pro, Bio-Printer ${ }^{\mathrm{TM}}-\mathrm{WS}$ ), has already been used in bioprinting multiple tissue types, including liver and human ear cartilage constructs [63]. Regenovo bioprinters not only function in aseptic conditions, but also have temperature-controlled cartridges supporting bioprinting of various bioink solutions with temperatures ranging from -5 to $260^{\circ} \mathrm{C}$.

REGEMAT 3D. REGEMAT 3D company, founded in Spain, focuses on 3D bioprinting technologies that offer diverse bioprinting capabilities [47]. The company produced their first commercially available 3D bioprinter system called REGEMAT 3D V1 (see Figure 2E), a multi-head system, which allows bioprinting of multiple types of biomaterials. REGEMAT 3D $\mathrm{V}^{1}$ enables pore filling (IPF), injection filling (IF) or fused deposition modeling (FDM) processes using REGEMAT's 
printhead technologies. Additionally, REGEMAT 3D V ${ }^{1}$ bioprinter and its components can be customized based on individual tissue bioprinting requirements such as adding cooling system and changing print heads.

\subsubsection{Extrusion-based bioprinters with higher degrees of motion freedom}

BioAssemblyBot. Another recent bioprinter development emerged from Advanced Solutions in the US [48]. A 6-axis robotic bioprinter, called BioAssemblyBot, is capable of moving in six degrees of freedom in its workspace. BioAssemblyBlot was designed to assemble different hydrogel solutions encapsulating different cells. Therefore, a unique syringe storage feature has been integrated into the bioprinter, which enables loading and unloading of a standard syringe barrel automatically using the robot end effector. The bioprinter is integrated with a human machine interface system that allows loading CAD files and generating a robot path plan for hydrogel deposition. The system was built in an enclosure that can support a camera view and airline or electric or modem cable.

\subsubsection{Extrusion-based bioprinters supporting bioplotting process}

3D Bioplotter ${ }^{\circledR}$. 3D Bioplotter ${ }^{\circledR}$ was created by a research team at University of Freiburg in Germany [33], which was later commercialized by EnvisionTEC company. 3D Bioplotter ${ }^{\circledR}$ dispenses the bioink of various hydrogel solutions as well as biodegradable polymers and ceramics in order to structurally support tissue constructs [64]. The first version of the system used compressed air to force cut a liquid- or paste-like plotting medium, where the extruder-head could be heated to control viscosity [65]. The plotting medium refers to the medium in which the bioink solution is plotted; therefore, the viscosity of the bioink solutions should be compatible with that of the plotting medium. The extrusion behavior of the dispensed bioink solution can modulate the printing resolution and accuracy. The bioink solidifies when it comes in contact with the substrate or previous layer. The newer version of Bioplotter ${ }^{\circledR}$, as shown in Figure 2F, uses syringe-type pneumatic dispensers without a plotting medium as the plotting medium restricts the use of thermoplastic or inorganic ceramic materials [51]. Bioplotter ${ }^{\circledR}$ is equipped with an automated interchangeable cartridge system to print multiple bioink materials in one build eliminating the need for manual cartridge changes and recalibration. In addition, the automated nozzle tip cleaning 
mechanism eliminates the material build-up on nozzle tips. Using Bioplotter ${ }^{\circledR}$, various cell-laden hydrogels can be bioprinted including but not limited to gelatin, collagen, fibrin, alginate and agar. Researchers also utilized Bioplotter ${ }^{\circledR}$ to print inert bioresorbable scaffolds using hard polymeric and inorganic ceramic materials such as polycaprolactone (PCL), hydroxyapatite (HA) and tricalcium phosphate (TCP) particles [64].

\subsubsection{Extrusion-based bioprinters supporting bioprinting of cell aggregates}

NovoGen $M M X^{T M}$. NovoGen $\mathrm{MMX}^{\mathrm{TM}}$ bioprinter was commercialized by Organovo when the company was first launched. Although it is currently not commercially available, it has been extensively used by the company to bioprint various tissue types such as a liver model and a breast tissue model for cancer screening $[66,67]$. With its multi-head dispensers, NovoGen $\mathrm{MMX}^{\mathrm{TM}}$ was first used to bioprint tissue spheroids along with a support structure made of agarose hydrogel. After the bioprinting process, tissue spheroids fused together and further matured into a tissue-like organization. As this occurred, the agarose supporting mold was removed, thereby leaving a final bioprinted tissue [68]. This illustrated the fact that the cells were capable of rearranging themselves post-bioprinting thereby facilitating the rapid maturation of tissues. For example, blood vessels were bioprinted using aggregates of fibroblasts, endothelial and smooth muscle cells. Once bioprinted, with no technological intervention, endothelial cells migrated toward the luminal surface of the blood vessel and fibroblasts migrated toward the outer surface. As loading tissue spheroids is a challenging task [13], the company has recently bioprinted preaggregates into a designed shape for engineering of tissues for drug testing and cancer modeling using a new model of their bioprinter (see Figure $2 \mathrm{G}$ ).

nScrypt. nScrypt from the US previously manufactured a bioprinter for precise deposition of tissue spheroids comprised of two essential elements including a robotic precision position system and a fully automated computer-controlled dispensing system. In the early version of nScrypt bioprinter (with three printheads), the first two printheads (piston-driven) were used to bioprint tissue spheroids and the third one (pressure-driven) was used to print the biopaper substrate (i.e., collagen type I) [69]. The company currently offers the nScrypt 3Dn model (see Figure $2 \mathrm{H}$ ) for cell bioprinting, which can hold four 
different bioink solutions at a time and achieve high cell viability using the SmartPump ${ }^{\mathrm{TM}}$ dispenser [70]. The dispenser can bioprint a variety of ECM components such as collagen and hyaluronic acid in a heated or cooled condition. In addition, nScrypt 3Dn can also be mounted with a high-precision $\mathrm{nFD}^{\mathrm{TM}}$ printhead for deposition of a wide range of thermoplastic-based biopolymers.

\subsubsection{Extrusion-based bioprinters supporting other bioprinting modalities}

Bio3D SYN^ and Bio3D Explorer. Bio3D Technologies from Singapore has developed two different 3D bioprinting platforms including "Bio3D SYN^" and "Bio3D Explorer [57]." Bio3D SYN^ was designed with a high resolution (around $1 \mu \mathrm{m}$ ) for each axes. Bio3D SYN^ not only facilitates EBB but also jetting and photo-polymerization. This bioprinter has brought a new concept as it offers multiple configurations for different bioprinting modalities. Bio3D SYN^ has an anti-vibration levitation build platform, which enables precise control on the distance between the nozzle tip and the platform [57]. In addition, Bio3D SYN^ enables real-time monitoring of the process as it possesses an advanced control mechanism. Bio3D SYN$\wedge$ is capable of bioprinting multiple types of biomaterials for the fabrication of living tissue substitutes. Bio3D Explorer is a less sophisticated version than Bio3D SYN^ with a motion resolution five times less than that of Bio3D SYN^ . One of the major advantages of this bioprinter is that it offers a portable system which can operate up to four printheads.

Biofactory and 3D Discovery ${ }^{\circledR}$. Biofactory is a highly versatile 3D bioprinter manufactured by Delta-Robotics, which is currently known as regenHU from Switzerland [71]. Biofactory bioprinters accommodate a wide range of bioprinting modalities including extrusion- and droplet-based bioprinting (DBB) techniques. Therefore, Biofactory allows work with a wide range of biomaterials including photocrosslinkable hydrogels (wavelength of $355 \mathrm{~nm}$ ), proteins and high viscosity biomaterials [71]. Biofactory is a built-in system in a laminar flow hood maintaining a sterile environment with a controlled temperature, humidity and gas composition. Researchers have recently used Biofactory bioprinters in various applications, such as skin tissue regeneration [72], in-vitro modeling [59], and 3D tubular construct [73]. 3D Discovery ${ }^{\circledR}$ bioprinter is capable of dispensing up to four different materials in 2D or 
3D using multiple fluid-dispenser heads (droplet-based) or printer-heads (extrusion-based) [23]. The fluid dispenser-head can dispense as little as a picoliter enabling fabrication of high-throughput arrays on wellplates of various dimensions for chemotaxis assays. The bioprinter has heating (up to $80{ }^{\circ} \mathrm{C}$ ) and cooling chambers allowing bioprinting of biomaterials with a wider range of viscosities.

\section{2. $\quad$ Droplet-based Bioprinters}

Engineering tissues with native-like characteristics is not trivial [74]. Droplet-based bioprinting, among all of the available bioprinting modalities, fabricates tissues with comparable native-like characteristics because of its ability to bioprint various cell types accurately and simultaneously [75]. Droplet-based bioprinting was first demonstrated by Klebe in the 1980s [16] and further developed by Boland in the 2000s [76-79]. The two groups customized commercially available HP and Canon (thermal drop-on-demand (DOD)) paper printers to bioprint various proteins and cell types. However, paper printers are not suitable for bioprinting applications due to their closed architecture. The printheads, for example, move along only one axis and are not capable of bioprinting in 2D or 3D. Hence, 2D and 3D construct fabrication requires the introduction of an additional substrate movement, which at times is difficult to integrate. As a result, Nakamura's group at University of Toyama built their own bioprinter using commercially available stepper motors and EPSON SEA-Jet ${ }^{\mathrm{TM}}$ printhead to overcome the limitations of the paper printers. The bioprinter was employed to fabricate hollow cylindrical tissue constructs at improved (millimeter-scale) resolution [80].

Commercially available multi-nozzle inkjet printheads such as EPSON SEA-Jet ${ }^{\mathrm{TM}}$ (electrostatic DOD), Fuji Dimatix ${ }^{\mathrm{TM}}$ (piezoelectric DOD) and Xaar-126 (piezoelectric DOD) have since been used for bioprinting various cell types and several other biologics [80-82]. The printheads generate droplets of 1100 pico-liters in volume (droplet diameters of 10-60 $\mu \mathrm{m}$ ), requiring very small nozzle orifice diameters. Thus, the printheads are prone to clogging when bioprinting viscous or fibrous bioink such as cell-laden collagen [83]. Consequently, a very limited number of cell types and biologics are bioprintable using these printheads. At the same time, single nozzle piezoelectric dispensers, including but not limited to, 
Microfab Technologies MJ series, Microdrop Technologies MD series and Nordson Pico® series are versatile and offer greater control over droplet generation and placement. Hence, the dispensers have been extensively used for high-throughput and high-resolution bioprinting applications [84-86]. However, small secondary droplets known as satellite droplets often accompany the primary droplets [87] and can reduce the bioprinting accuracy and precision [86]. Similar to multi-nozzle inkjet printheads, the single nozzle dispensers are prone to clogging when bioprinting viscous bioinks.

Micro-valve bioprinters, in contrast, have not been reported to generate satellite droplets to date. Commercially available micro-valve dispensers such as TechElan G100-150300NJ, Fritz Gyger SMLD, Offshore Solutions micro-valve nozzle and Lee Products VHS nanolitre dispense valve have been used for bioprinting a myriad of living cells and other biologics [59, 73-82]. However, the dispensers generate larger droplets compare to other DBB modalities under identical conditions [98]. Hence, they are not suitable for high-resolution bioprinting applications. In contrast, electrohydrodynamic jet (EHD) bioprinters are capable of generating droplets that are smaller than the nozzle orifice opening (diameter) [99-101]. Thus, these bioprinters are suitable for propelling highly concentrated bioinks (up to $20 \%$ weight by volume) through extremely small nozzles (orifice diameters $\leq 100 \mu \mathrm{m}$ ) [99]. Several in-house built EHD bioprinters, assembled from commercially available components, have been used to bioprint various biologics such as living cells and proteins [102-106]. But, these bioprinters eject a continuous jet or a stream of multiple droplets at a time [107-109] and are not ideal for high precision bioprinting applications.

Unlike inkjet, EHD, or micro-valve bioprinters where droplets are ejected through a nozzle [110], acoustic bioprinters employ a gentle acoustic field to eject droplets from an open pool of bioink solution without using a nozzle. Constituent living cells of the bioink are consequently not subjected to detrimental stressors such as heat, high pressure, large voltage, and shear stress during droplet ejection. However, 3D construct fabrication requires printhead and/or substrate movement which can introduce undesirable disturbances. As a result, the disturbances can diminish control over the droplet generation and placement in acoustic bioprinting. In addition, the bioprinters may not be suitable for bioprinting 
viscous bioinks such as cell-laden collagen as the gentle acoustic waves may not be sufficient to generate droplets. Thus, acoustic bioprinters have been employed only for bioprinting a select few biologics [110,111].

Overall, in-house assembled bioprinters using commercially available components, are economical and offer greater freedom; however, their design is time consuming at times and requires specialized skills and knowledge in the areas of electrical and computer engineering, pertaining to system integration. A typical 3D bioprinter, for instance, requires coordinated movement of printhead and substrate along the three axes and a software program to control the movement as well as the droplet jetting mechanism, according to print job file or the operator's input. On the other hand, commercially available complete bioprinting systems have well-integrated subsystems and save the user development time. However, they are expensive and may limit the level of customization. Table 2 presents the commercially available and non-commercial droplet-based bioprinters along with their application areas. A limited number of complete bioprinting systems are commercially available, which are discussed herein.

Autodrop Compact and AD-P-8000. Autodrop Compact bioprinters by Microdrop Technologies (Germany) rely on piezoelectric drop-on-demand inkjet (PIJ) mechanism to generate droplets [112]. Bioink solution in PIJ bioprinters is stored in a fluid reservoir and is held in place at the nozzle orifice because of the surface tension [113]. A voltage pulse is applied to deform the piezoelectric actuator of the bioprinter which in turn deforms the fluid reservoir [114]. The sudden change in the volume of the fluid reservoir causes a pressure wave. Consequently, a droplet of the bioink is ejected when the surface tension at the nozzle orifice is overcome [115]. Some PIJ bioprinters also require pneumatic pressure (static pressure through means of pressurized-air) commonly referred to as the back pressure to supplement the pressure pulses to overcome the surface tension at the nozzle orifice. Autodrop Compact bioprinters, as the name indicates, are compact PIJ bioprinters. Their substrate dimensions are $200 \times 200$ $\mathrm{mm}$. At the same time, the bioprinters position accuracy ( $\mathrm{x}-\mathrm{y}-\mathrm{z}$ axes) is $\pm 25 \mu \mathrm{m}$ and the travel-velocity is $75 \mathrm{~mm} / \mathrm{s}$ (acceleration $500 \mathrm{~mm} / \mathrm{s}^{2}$ ). Further, the payload capacity of the bioprinters is $5 \mathrm{~kg}$ for $\mathrm{y}$-axis and 1 
$\mathrm{kg}$ for $\mathrm{x}$ - and $\mathrm{z}$-axis. An electronic controller is provided to regulate the voltage pulse characteristics and the simultaneous operation of up to two piezoelectric dispensers. Similarly, a graphical editor is provided for defining custom design patterns and it also supports the import of vector-based graphic files. Autodrop AD-P-8000 bioprinters have better accuracy, greater travel-velocity and higher payload capacity than Autodrop Compact bioprinters. The position accuracy ( $\mathrm{x}-\mathrm{y})$ of the bioprinters is $\pm 5 \mu \mathrm{m}$ and the travel-velocity is $125 \mathrm{~mm} / \mathrm{s}$ (acceleration $1,000 \mathrm{~mm} / \mathrm{s}^{2}$ ). Further, the payload capacity of the bioprinters is $10 \mathrm{~kg}$ for $\mathrm{y}$-axis and $1.5 \mathrm{~kg}$ for $\mathrm{x}$ - and $\mathrm{z}$-axis. The included electronic controller simultaneously supports up to eight piezoelectric dispensers. This model is comparable to the Autodrop Compact in all other aspects.

MicroFab jetlab ${ }^{\circledR}$. MicroFab jetlab ${ }^{\circledR}$ bioprinters from MicroFab Solutions Inc. from the US employ PIJ mechanism to generate droplets and are available in two configurations, jetlab® II (see Figure 3A) and jetlab® 4 (see Figure 3B) [116]. The jetlab® 4 is compact and relatively inexpensive compared to jetlab® II. The substrate size of jetlab® 4 is $160 \times 120 \mathrm{~mm}$ as compared to $200 \times 200 \mathrm{~mm}$ of jetlab® II. However, jetlab ${ }^{\circledR}$ II has higher positioning (x-y axes) accuracy of $\pm 15 \mu \mathrm{m}$ than jetlab® 4 , which is \pm 30 $\mu \mathrm{m}$. In addition, jetlab® II is faster $\left(100 \mathrm{~mm} / \mathrm{s}\right.$ velocity and $400 \mathrm{~mm} / \mathrm{s}^{2}$ acceleration) than jetlab® $4(50$ $\mathrm{mm} / \mathrm{s}$ velocity and $1,500 \mathrm{~mm} / \mathrm{s}^{2}$ acceleration). Furthermore, jetlab® II has greater payload capacity (x and y stage maximum payload is $10 \mathrm{~kg}$ and $\mathrm{z}$ stage maximum payload is $3 \mathrm{~kg}$ ) than jetlab® 4 ( $\mathrm{x}$ and y stage maximum payload is $20 \mathrm{~kg}$ and $\mathrm{z}$ stage maximum payload is $5 \mathrm{~kg}$ ). The two configurations are available with various integrated control mechanisms for regulating motion, pneumatic pressure, voltage pulse generation and pulse characteristics, temperature and alignment. In addition, a software graphical user interface is provided to define the process parameters. Hence, very little training is necessary for the bioprinter's operation. 
Table 2. Droplet-based Bioprinters

\begin{tabular}{|c|c|c|c|c|c|c|c|c|}
\hline & 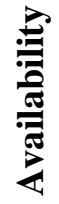 & $\begin{array}{l}\text { Bioprinter } \\
\text { Name }\end{array}$ & Country & Droplet Mechanism & $\begin{array}{l}\text { University/ } \\
\text { Company }\end{array}$ & Use & $\begin{array}{l}\text { Dual bioink } \\
\text { Printability }\end{array}$ & $\begin{array}{c}\text { Year of } \\
\text { Market } \\
\text { Introduction }\end{array}$ \\
\hline \multirow{9}{*}{ 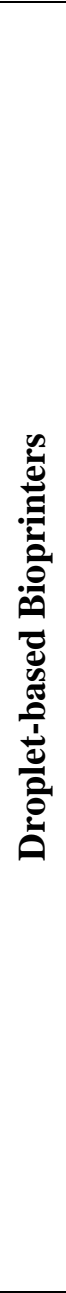 } & \multirow{7}{*}{ 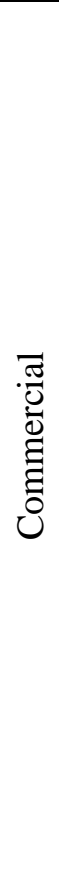 } & $\begin{array}{c}\text { Fujifilm } \\
\text { Dimatrix Printer }\end{array}$ & USA & $\begin{array}{l}\text { Piezoelectric Drop-on- } \\
\text { demand }\end{array}$ & $\begin{array}{c}\text { FUJIFILM } \\
\text { Dimatix, Inc. }\end{array}$ & $\begin{array}{l}\text { Study of cell-to-cell communications } \\
\text { among bioprinted bacterial cells [81] }\end{array}$ & - & $2005[117]$ \\
\hline & & $\begin{array}{l}\text { MicroFab } \\
\text { JetLab II }\end{array}$ & USA & $\begin{array}{l}\text { Piezoelectric Drop-on- } \\
\text { demand }\end{array}$ & $\begin{array}{l}\text { MicroFAB } \\
\text { Technologies, } \\
\text { Inc. }\end{array}$ & $\begin{array}{l}\text { Cell and biologics 3D bioprinting } \\
\text { including silk nest arrays for hosting } \\
\text { cells (E.coli) for biosensing [84] }\end{array}$ & + & $2000^{¥}$ \\
\hline & & $\begin{array}{l}\text { MicroFab } \\
\text { JetLab } 4\end{array}$ & USA & $\begin{array}{l}\text { Piezoelectric Drop-on- } \\
\text { demand }\end{array}$ & $\begin{array}{l}\text { MicroFAB } \\
\text { Technologies, } \\
\text { Inc. }\end{array}$ & Bioprinting & + & $2006^{¥}$ \\
\hline & & $\begin{array}{l}\text { Autodrop } \\
\text { Compact }\end{array}$ & Germany & $\begin{array}{l}\text { Piezoelectric Drop-on- } \\
\text { demand }\end{array}$ & $\begin{array}{l}\text { Microdrop } \\
\text { Technologies }\end{array}$ & Bioprinting & + & $2008^{¥}$ \\
\hline & & $\begin{array}{l}\text { Autodrop AD-P- } \\
8000\end{array}$ & Germany & $\begin{array}{l}\text { Piezoelectric Drop-on- } \\
\text { demand }\end{array}$ & $\begin{array}{c}\text { Microdrop } \\
\text { Technologies }\end{array}$ & Bioprinting & + & $2004^{¥}$ \\
\hline & & $\begin{array}{l}\text { Cluster } \\
\text { Technology } \\
\text { DeskViewer }\end{array}$ & Japan & $\begin{array}{l}\text { Piezoelectric Drop-on- } \\
\text { demand }\end{array}$ & $\begin{array}{l}\text { Cluster } \\
\text { Technology Co., } \\
\text { Ltd. }\end{array}$ & $\begin{array}{c}\text { Human liver tissue chips comprising } \\
\text { of hepatocytes (HepG2) and human } \\
\text { umbilical vein endothelial cells } \\
\text { (HUVECs) [118] }\end{array}$ & + & N/A \\
\hline & & $\begin{array}{l}\text { Cell Jet Cell } \\
\text { Printer }\end{array}$ & USA & $\begin{array}{l}\text { synQUAD drop-by- } \\
\text { drop technology } \\
\text { (micro-valve and } \\
\text { syringe pump) } \\
\end{array}$ & Digilab, Inc. & Cell Printing & + & $2015^{¥}$ \\
\hline & \multirow[t]{2}{*}{ 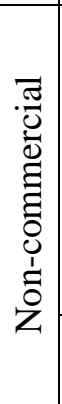 } & $\begin{array}{c}\text { Custom printer } \\
\text { with MicroJet }^{\mathrm{TM}} \\
\text { piezoelectric } \\
\text { actuator with } \\
\text { MicroFab } \\
\text { Technologies } \\
\text { nozzle }\end{array}$ & USA & $\begin{array}{l}\text { Piezoelectric Drop-on- } \\
\text { demand }\end{array}$ & $\begin{array}{l}\text { Carnegie Mellon } \\
\text { University and } \\
\text { University of } \\
\text { Pittsburgh } \\
\text { Medical Center } \\
\text { (UPMC) }\end{array}$ & $\begin{array}{l}\text { FGF-2 dose impact on human MG- } \\
63 \text { osteosarcoma cell response } \\
{[119,120], \text { BMP-2 to evaluate }} \\
\text { spatially controlled differentiation of } \\
\text { MDSCs [121] }\end{array}$ & - & N/A \\
\hline & & $\begin{array}{l}\text { Custom printer } \\
\text { with MicroFab }\end{array}$ & Canada & $\begin{array}{l}\text { Piezoelectric Drop-on- } \\
\text { demand }\end{array}$ & $\begin{array}{l}\text { University of } \\
\text { British Columbia }\end{array}$ & $\begin{array}{l}\text { MCF-7 movement within in the } \\
\text { nozzle during the printing process }\end{array}$ & - & N/A \\
\hline
\end{tabular}




\begin{tabular}{|c|c|c|c|c|c|c|}
\hline $\begin{array}{l}\text { MJ-ABP-01 } \\
\text { piezoelectric } \\
\text { nozzle }\end{array}$ & & & & [122] & & \\
\hline $\begin{array}{l}\text { Custom printer } \\
\text { with MicroFab } \\
\text { MJ-ABL-01- } \\
\text { 120-6MX } \\
\text { piezoelectric } \\
\text { nozzle } \\
\end{array}$ & USA & $\begin{array}{l}\text { Piezoelectric Drop-on- } \\
\text { demand }\end{array}$ & $\begin{array}{l}\text { Clemson } \\
\text { University and } \\
\text { University of } \\
\text { Florida }\end{array}$ & $\begin{array}{c}\text { Complex tubular tissue (NIH } 3 \mathrm{~T} 3 \\
\text { cells and alginate) constructs with } \\
\text { bifurcations }[85,86]\end{array}$ & - & N/A \\
\hline $\begin{array}{l}\text { Modified Canon } \\
\text { Bubble Jet } \\
\text { printer (BJC- } \\
\text { 2100) and } \\
\text { modified } \\
\text { Hewlett-Packard } \\
\text { Deskjet printers } \\
\text { (HP 550C, HP } \\
\text { 500, and HP } \\
340 \text { ) }\end{array}$ & USA & $\begin{array}{l}\text { Thermal drop-on- } \\
\text { demand }\end{array}$ & $\begin{array}{l}\text { Clemson } \\
\text { University and } \\
\text { The University of } \\
\text { Texas at El Paso }\end{array}$ & $\begin{array}{l}\text { Collagen scaffolding patterns [123], } \\
\text { mammalian cell (CHO cells and rat } \\
\text { primary embryonic motoneural cells) } \\
\text { constructs [76], neural cell (rat } \\
\text { hippocampal and cortical cell) } \\
\text { constructs [77], alginate 3D } \\
\text { constructs [78], cardiac 3D } \\
\text { constructs (feline and H1 } \\
\text { cardiomyocytes with alginate), } \\
\text { vascular (HMVECs and Fibrin) } \\
\text { constructs [124], skin transplants } \\
\text { (NHDF and NHEK) with built-in } \\
\text { vascular networks (HMVECs) for } \\
\text { in-vivo wound healing studies [125] }\end{array}$ & + & N/A \\
\hline $\begin{array}{l}\text { Modified } \\
\text { Hewlett-Packard } \\
\text { Deskjet printer } \\
\text { (HP 550C) }\end{array}$ & USA & $\begin{array}{l}\text { Thermal drop-on- } \\
\text { demand }\end{array}$ & $\begin{array}{l}\text { Wake Forest } \\
\text { University }\end{array}$ & $\begin{array}{l}\text { Alginate microspheres with single- } \\
\text { encapsulated-cells (beta-TC6) } \\
\text { [126], complex heterogeneous 3D } \\
\text { tissue models with hAFCS, dSMCs, } \\
\text { and bECs [127] }\end{array}$ & + & N/A \\
\hline $\begin{array}{l}\text { Modified } \\
\text { Hewlett-Packard } \\
\text { Deskjet printer } \\
\text { (HP 500) }\end{array}$ & USA & $\begin{array}{l}\text { Thermal drop-on- } \\
\text { demand }\end{array}$ & $\begin{array}{c}\text { The Scripps } \\
\text { Research Institute }\end{array}$ & $\begin{array}{l}\text { In-situ bioprinting of chondrocytes } \\
\text { and PEGDMA hydrogel for direct } \\
\text { cartilage repair [128], cartilage } \\
\text { constructs (human articular } \\
\text { chondrocytes) to study FGF-2 and } \\
\text { TGF- } \beta 1 \text { growth factors impact on } \\
\text { printed cartilage formation [129] }\end{array}$ & + & N/A \\
\hline Modified & USA & Thermal Drop-on- & TeVido & Breast Tissue & + & N/A \\
\hline
\end{tabular}




\begin{tabular}{|c|c|c|c|c|c|c|}
\hline $\begin{array}{l}\text { Hewlett-Packard } \\
\text { Ink-Jet Printer }\end{array}$ & & demand & BioDevices & & & \\
\hline $\begin{array}{c}\text { Modified } \\
\text { Hewlett-Packard } \\
\text { Deskjet printer }\end{array}$ & $\begin{array}{l}\text { USA, } \\
\text { Germany, } \\
\text { Japan and } \\
\text { China }\end{array}$ & $\begin{array}{l}\text { Thermal Drop-on- } \\
\text { demand }\end{array}$ & $\begin{array}{c}\text { Stemorgan } \\
\text { Therapeutics, } \\
\text { Technical } \\
\text { University } \\
\text { Munich, The } \\
\text { Scripps Research } \\
\text { Institute, Tokyo } \\
\text { University of } \\
\text { Science, } \\
\text { Rensselaer } \\
\text { Polytechnic } \\
\text { Institute, Wuhan } \\
\text { University of } \\
\text { Technology }\end{array}$ & $\begin{array}{l}\text { Stem cell tissue constructs (hMSCs } \\
\text { with PEG) and their directed } \\
\text { differentiation into bone and } \\
\text { cartilage }[130,131]\end{array}$ & + & N/A \\
\hline $\begin{array}{c}\text { Modified } \\
\text { Hewlett-Packard } \\
5360 \text { printer }\end{array}$ & $\begin{array}{l}\text { USA and } \\
\text { China }\end{array}$ & $\begin{array}{l}\text { Thermal Drop-on- } \\
\text { demand }\end{array}$ & $\begin{array}{c}\text { University of } \\
\text { Texas at El Paso, } \\
\text { Shanghai Jiao } \\
\text { Tong University, } \\
\text { Sun Yat-sen } \\
\text { University, and } \\
\text { Texas Tech } \\
\text { University Health } \\
\text { Sciences }\end{array}$ & $\begin{array}{l}\text { High-throughput miniature drug- } \\
\text { screening platform employing } \\
\text { bioprinted E. coli-laden alginate and } \\
\text { three different antibiotics } \\
\text { (penicillin/streptomycin, } \\
\text { antimycotic, and kanamycin sulfate) } \\
\text { [132] }\end{array}$ & + & N/A \\
\hline Lab-on-a-printer & Canada & $\begin{array}{l}\text { Microchannel-based } \\
\text { thermal inkjet }\end{array}$ & $\begin{array}{c}\text { Aspect } \\
\text { Biosystems }\end{array}$ & $\begin{array}{l}\text { 3D tissue fabrication, drug testing, } \\
\text { toxicity testing }\end{array}$ & + & N/A \\
\hline $\begin{array}{c}\text { Modified } \\
\text { Hewlett-Packard } \\
\text { (HP 660C) } \\
\text { printer with add- } \\
\text { on piezoelectric } \\
\text { pump }\end{array}$ & USA & $\begin{array}{l}\text { Piezoelectric Drop-on- } \\
\text { demand }\end{array}$ & $\begin{array}{l}\text { Clemson } \\
\text { University }\end{array}$ & $\begin{array}{l}\text { Protein (bovine serum albumin and } \\
\text { streptavidin) and cell (bovine aortal } \\
\text { endothelial cell) 2D constructs [18] }\end{array}$ & N/A & N/A \\
\hline $\begin{array}{l}\text { Custom printer } \\
\text { with Epson } \\
\text { SEA-Jet }\end{array}$ & Japan & $\begin{array}{l}\text { Electrostatic Drop-on- } \\
\text { Demand }\end{array}$ & $\begin{array}{l}\text { University of } \\
\text { Toyama and } \\
\text { Kanagawa }\end{array}$ & $\begin{array}{l}\text { 3D tissue (HeLa cells) constructs } \\
\text { (hollow tubes) [80] }\end{array}$ & - & N/A \\
\hline
\end{tabular}




\begin{tabular}{|c|c|c|c|c|c|c|}
\hline printhead & & & $\begin{array}{l}\text { Academy of } \\
\text { Science and } \\
\text { Technology }\end{array}$ & & & \\
\hline Custom Printer & $\begin{array}{l}\text { Ireland } \\
\text { and } \\
\text { Germany }\end{array}$ & $\begin{array}{l}\text { Piezoelectric Drop-on- } \\
\text { demand }\end{array}$ & $\begin{array}{l}\text { University of } \\
\text { Freiburg, Trinity } \\
\text { College and } \\
\text { Women and } \\
\text { Infants } \\
\text { University } \\
\text { Hospital }\end{array}$ & $\begin{array}{c}\text { Microspheres with single- } \\
\text { encapsulated-cells (HeLa cells) } \\
{[133]}\end{array}$ & - & N/A \\
\hline $\begin{array}{l}\text { Custom printer } \\
\text { with Xaar-126 } \\
\text { piezoelectric } \\
\text { print head } \\
\end{array}$ & Australia & $\begin{array}{l}\text { Piezoelectric Drop-on- } \\
\text { demand }\end{array}$ & $\begin{array}{l}\text { University of } \\
\text { Wollongong }\end{array}$ & $\begin{array}{l}\text { 2D tissue }(\mathrm{C} 2 \mathrm{C} 12 \text { and } \mathrm{PC} 12 \text { cells }) \\
\text { constructs }[82]\end{array}$ & + & N/A \\
\hline $\begin{array}{l}\text { Custom EHD } \\
\text { printer using } \\
\text { commercially } \\
\text { available } \\
\text { subsystems }\end{array}$ & UK & $\begin{array}{l}\text { Electrohydrodynamic } \\
\text { (EHD) jetting }\end{array}$ & $\begin{array}{l}\text { University of } \\
\text { London }\end{array}$ & $\begin{array}{l}\text { EHD as a viable bioprinting strategy } \\
\text { using Jurkat cells [99], CAD (Cath.- } \\
\text { a-differentiated) mouse neural cells } \\
\text { [102], human astrocytoma cells } \\
\text { [134], white blood cells, } \\
\text { erythrocytes [135], and THP-1 cells } \\
\text { with alginate and collagen [103] }\end{array}$ & - & N/A \\
\hline $\begin{array}{l}\text { Custom EHD } \\
\text { printer using } \\
\text { commercially } \\
\text { available } \\
\text { subsystems }\end{array}$ & Singapore & $\begin{array}{l}\text { Electrohydrodynamic } \\
\text { (EHD) jetting }\end{array}$ & $\begin{array}{l}\text { National } \\
\text { University of } \\
\text { Singapore and } \\
\text { Molecular } \\
\text { Engineering of } \\
\text { Biological and } \\
\text { Chemical } \\
\text { Systems }\end{array}$ & $\begin{array}{c}\text { Microencapsulation of cells } \\
\text { (Hepatocytes G2 cells) with alginate } \\
{[104]}\end{array}$ & - & N/A \\
\hline $\begin{array}{c}\text { Custom EHD } \\
\text { printer using } \\
\text { commercially } \\
\text { available } \\
\text { subsystems } \\
\end{array}$ & $\begin{array}{l}\text { South } \\
\text { Korea }\end{array}$ & $\begin{array}{l}\text { Electrohydrodynamic } \\
\text { (EHD) jetting }\end{array}$ & $\begin{array}{l}\text { Yonsei } \\
\text { University }\end{array}$ & Collagen scaffold patterns [105] & - & N/A \\
\hline $\begin{array}{l}\text { Custom EHD } \\
\text { printer using }\end{array}$ & USA & $\begin{array}{l}\text { Electrohydrodynamic } \\
\text { (EHD) jetting }\end{array}$ & $\begin{array}{l}\text { University of } \\
\text { Illinois at }\end{array}$ & $\begin{array}{l}\text { Rabbit Immunoglobulin-G and } \\
\text { fibronectin scaffold patterns [106] }\end{array}$ & - & N/A \\
\hline
\end{tabular}




\begin{tabular}{|c|c|c|c|c|c|c|}
\hline $\begin{array}{l}\text { commercially } \\
\text { available } \\
\text { subsystems }\end{array}$ & & & $\begin{array}{c}\text { Urbana- } \\
\text { Champaign, } \\
\text { University of } \\
\text { Michigan, and } \\
\text { Rensselaer } \\
\text { Polytechnic } \\
\text { Institute }\end{array}$ & & & \\
\hline $\begin{array}{l}\text { Custom EHD } \\
\text { printer using } \\
\text { commercially } \\
\text { available } \\
\text { subsystems }\end{array}$ & Italy & $\begin{array}{l}\text { Electrohydrodynamic } \\
\text { (EHD) jetting }\end{array}$ & $\begin{array}{l}\text { University of } \\
\text { Trento }\end{array}$ & $\begin{array}{c}\text { Microencapsulation of cells (B50 rat } \\
\text { neural cells) with alginate [136], 3T3 } \\
\text { fibroblasts and alginate constructs } \\
\text { [109] }\end{array}$ & - & N/A \\
\hline $\begin{array}{l}\text { Custom acoustic } \\
\text { picolitre droplet } \\
\text { ejection system }\end{array}$ & USA & $\begin{array}{l}\text { Acoustic droplet } \\
\text { ejection }\end{array}$ & $\begin{array}{l}\text { Harvard } \\
\text { University }\end{array}$ & $\begin{array}{l}\text { Encapsulation of a single to multiple } \\
\text { cells (mESC, RAJI, HL-1, 3T3, and } \\
\text { AML-12) [110] }\end{array}$ & + & N/A \\
\hline $\begin{array}{l}\text { Custom acoustic } \\
\text { droplet ejection } \\
\text { system }\end{array}$ & USA & $\begin{array}{l}\text { Acoustic droplet } \\
\text { ejection }\end{array}$ & $\begin{array}{l}\text { University of } \\
\text { Michigan }\end{array}$ & $\begin{array}{l}\text { 2D heterogeneous tissue (MDA MB } \\
231 \text { breast cancer cells and HEK } 239 \\
\text { cells with dextran) constructs [111] }\end{array}$ & - & N/A \\
\hline $\begin{array}{l}\text { Custom printer } \\
\text { with TechElan } \\
\text { solenoid valve } \\
\text { ejector (G100- } \\
150300 \mathrm{nj})\end{array}$ & $\begin{array}{l}\text { USA and } \\
\text { Finland }\end{array}$ & $\begin{array}{l}\text { Micro-valve } \\
\text { (Solenoid) }\end{array}$ & $\begin{array}{l}\text { Harvard } \\
\text { University, } \\
\text { Massachusetts } \\
\text { Institute of } \\
\text { Technology, } \\
\text { Clemson } \\
\text { University, and } \\
\text { University of } \\
\text { Helsinki }\end{array}$ & $\begin{array}{l}\text { Cells (mESC, RAJI, HL-1, 3T3, and } \\
\text { AML-12) encapsulation, cell } \\
\text { encapsulation (rat bladder smooth } \\
\text { muscle cells with collagen) [88], 3D } \\
\text { tissue constructs ( rat bladder smooth } \\
\text { muscle cells and collagen) } \\
\text { fabrication [89], heterogeneous } \\
\text { tissue (NIH: OVCAR-5 human } \\
\text { ovarian cancer cells and MRC-5 } \\
\text { normal human fibroblasts) constructs } \\
\text { [90], 3D fibrocartilage tissue models } \\
\text { by bioprinting mesenchymal stem } \\
\text { cells with GelMA precursor solution } \\
\text { and photointiator [91] }\end{array}$ & + & N/A \\
\hline $\begin{array}{l}\text { Custom printer } \\
\text { with Fritz Gyger } \\
\text { SMLD solenoid } \\
\text { valve ejector }\end{array}$ & $\begin{array}{l}\text { USA and } \\
\text { South } \\
\text { Korea }\end{array}$ & $\begin{array}{l}\text { Micro-valve } \\
\text { (Solenoid) }\end{array}$ & $\begin{array}{l}\text { Harvard Medical } \\
\text { School, } \\
\text { Rensselaer } \\
\text { Polytechnic }\end{array}$ & $\begin{array}{l}\text { 3D skin tissue (human dermal } \\
\text { fibroblasts, human epidermal } \\
\text { keratinocytes, and collagen) } \\
\text { constructs [92], 2D neural tissue (rat }\end{array}$ & + & N/A \\
\hline
\end{tabular}




\begin{tabular}{|c|c|c|c|c|c|c|}
\hline & & & $\begin{array}{l}\text { Institute, Albany } \\
\text { Medical College, } \\
\text { and Korea } \\
\text { Advanced } \\
\text { Institute of } \\
\text { Science and } \\
\text { Technology } \\
\text { (KAIST) }\end{array}$ & $\begin{array}{c}\text { astrocytes, neurons, and collagen) } \\
\text { constructs [137], VEGF-releasing } \\
\text { fibrin gel scaffolds for neural stem } \\
\text { cell (murine NSC) culture [93] } \\
\text { Angiogenic sprouting of vascular } \\
\text { networks at cellular level through } \\
\text { bioprinted HUVECs and NHLFs } \\
{[94]}\end{array}$ & & \\
\hline $\begin{array}{l}\text { Custom printer } \\
\text { with Offshore } \\
\text { Solutions } \\
\text { solenoid inkjet } \\
\text { valve } \\
\end{array}$ & USA & $\begin{array}{l}\text { Micro-valve } \\
\text { (Solenoid) }\end{array}$ & $\begin{array}{l}\text { Wake Forest } \\
\text { University }\end{array}$ & $\begin{array}{c}\text { Cartilage tissue constructs } \\
\text { (chondrocytes, fibrinogen, and } \\
\text { collagen) [74] }\end{array}$ & - & N/A \\
\hline $\begin{array}{l}\text { Custom printer } \\
\text { with Lee } \\
\text { Products VHS } \\
\text { Nanolitre } \\
\text { Dispense valve } \\
\text { with Lee } \\
\text { Products } \\
\text { Minstac Nozzle }\end{array}$ & UK & $\begin{array}{l}\text { Micro-valve } \\
\text { (Solenoid) }\end{array}$ & $\begin{array}{c}\text { Heriot-Watt } \\
\text { University and } \\
\text { Roslin Biocentre }\end{array}$ & $\begin{array}{l}\text { Tissue (HEK293 and hESC cells) } \\
\text { spheroids [95], 3D hepatocyte } \\
\text { constructs (HLCs differentiated from } \\
\text { hESCs and hiPSCs with alginate) } \\
\text { [96], DNA based hydrogel } \\
\text { bioprinting [97] }\end{array}$ & + & N/A \\
\hline Custom printer & Australia & $\begin{array}{l}\text { Micro-valve } \\
\text { (Solenoid) }\end{array}$ & $\begin{array}{l}\text { University of } \\
\text { Wollongong }\end{array}$ & $\begin{array}{c}\text { 2D tissue }(\mathrm{C} 2 \mathrm{C} 12 \text { cells) constructs } \\
{[82]}\end{array}$ & - & N/A \\
\hline
\end{tabular}

N/A - Information not available.

+ Capable of bioprinting one or more bioink at a time.

- Capable of bioprinting only one bioink at a time.

¥ Information has been obtained from the company. 


\subsection{Laser-based Bioprinters}

Laser-based bioprinting (LBB) relies on two different mechanisms (weakly focused beam and focused laser pulses), laser-guided direct writing (LGDW) [17,138] and modified laser-induced forward transfer (LIFT) [139,140], to deposit bioink droplets. Laser-guided direct writing employs optical trapping forces of a weakly focused laser beam for guided disposition of individual biologics such as living cells with micrometer-scale accuracy [141-144]. However, the refractive index of the individual biologics significantly impacts the magnitude of the optical forces (a $4 \%$ decrease in refractive index decreases the trapping force by four times and the pushing force by 25 times) [143]. Consequently, very few cell types and other biologics are bioprintable and hence LGDW bioprinters, in-house built from commercially available subsystems, have been used in a very few studies [17,138,142,143]. Modified LIFT-based bioprinters, in contrast, are suitable for bioprinting a myriad of biologics as they are nozzlefree and are not constrained by the viscosity of bioink solutions [145]. In addition, the bioprinters are suitable for fabricating complex 3D tissue constructs, including hollow tubular tissue constructs, as they are not limited by the bioink viscosity [146,147].

Bioprinters based on modified LIFT and its variations are known by various names such as matrix-assisted pulsed laser evaporation direct write (MAPLE DW) [139,148,149], biological laser printing (BioLP) [150,151], absorbing film assisted-LIFT (AFA-LIFT) [152] and laser-assisted bioprinting (LaBP) $[153,154]$. However, their principal working mechanism is the same [144]. That is, the bioprinters use focused laser pulses to generate bioink droplets by locally heating the bioink directly (MAPLE DW) or alternatively the absorbing interlayer (BioLP, LaBP and AFA-LIFT), which are applied as layers on a quartz ribbon support. The localized heating causes a vapor bubble, which rapidly expands and collapses, generating a pressure wave. The pressure wave consequently propels bioink droplets (or jets depending on the process parameters such as the bioink viscosity and laser energy) on to a receiving substrate $[151,155,156]$. Modified LIFT-based bioprinters have been used for bioprinting applications involving living cells such as stem cells [153,157] and other biologics such as proteins [139]. Although, the bioprinters are not constrained by the bioink viscosity, their bioprinting speed is limited by the ribbon 
preparation time at present [158] and is often slower than other bioprinting modalities. Nearly all of laserbased bioprinters (see Table 3), reported to date, rely on neodymium-doped yttrium aluminum garnet (Nd: YAG) or excimer (argon fluoride (ArF) or krypton fluoride $(\mathrm{KrF})$ ) lasers for pulse generation and have been assembled from commercially available subsystems. In-house built bioprinters are generally expensive as compared to EBB and DBB bioprinters. Currently, there are no commercially available laser-based bioprinters in the market. In addition to abovementioned laser-based bioprinters, stereolithography and its modifications have been used in bioprinting of living cells [159]; however, such technologies

are

beyond

the

scope

of

this

review. 
Table 3. Laser-based Bioprinters

\begin{tabular}{|c|c|c|c|c|c|c|c|}
\hline & 离 & $\begin{array}{l}\text { Bioprinter } \\
\text { Name }\end{array}$ & Country & $\begin{array}{c}\text { Laser } \\
\text { Mechanism }\end{array}$ & University/Institution & Use & $\begin{array}{c}\text { Dual } \\
\text { bioink } \\
\text { Printability }\end{array}$ \\
\hline \multirow{4}{*}{ 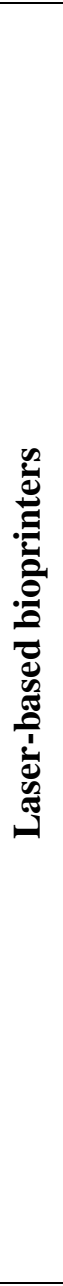 } & \multirow{4}{*}{ 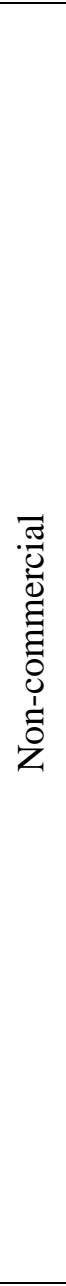 } & $\begin{array}{l}\text { Custom-built } \\
\text { laser-based } \\
\text { bioprinter }\end{array}$ & USA & LGDW & $\begin{array}{l}\text { University of Minnesota } \\
\text { and Michigan } \\
\text { Technological University }\end{array}$ & $\begin{array}{l}\text { Embryonic chick spinal cord cells to } \\
\text { demonstrate LGDW capabilities [138], 2D } \\
\text { and 3D HUVEC patterns on Matrigel [143] }\end{array}$ & - \\
\hline & & $\begin{array}{l}\text { Custom-built } \\
\text { laser-based } \\
\text { bioprinter }\end{array}$ & USA & LGDW & $\begin{array}{l}\text { Michigan Technological } \\
\text { University and University } \\
\text { of Missouri-Columbia }\end{array}$ & $\begin{array}{c}\text { Evaluation of laser-induced damage on } \\
\text { bioprinted avidin biomolecules (proteins) } \\
{[142]}\end{array}$ & - \\
\hline & & $\begin{array}{c}\text { Custom-built } \\
\text { laser-based } \\
\text { bioprinter based } \\
\text { on ArF excimer } \\
\text { laser }\end{array}$ & USA & $\begin{array}{l}\text { Modified } \\
\text { LIFT } \\
\text { (MAPLE } \\
\text { DW and } \\
\text { BioLP) }\end{array}$ & $\begin{array}{l}\text { US Naval Research } \\
\text { Laboratory }\end{array}$ & $\begin{array}{l}\text { Biotinylated bovine serum albumin (BSA) } \\
\text { protein microarray fabrication by using } \\
\text { MAPLE DW [139], 2D patterning of } \\
\text { human osteosarcoma and rat cardiac cells } \\
\text { by using MAPLE DW [160], 3D patterning } \\
\text { of human osteosarcoma cells by using } \\
\text { BioLP [151], single cell patterns of Human } \\
\text { osteosarcoma cells by using BioLP [161] }\end{array}$ & - \\
\hline & & $\begin{array}{c}\text { Custom-built } \\
\text { laser-based } \\
\text { bioprinter based } \\
\text { on ArF excimer } \\
\text { laser }\end{array}$ & & $\begin{array}{l}\text { Modified } \\
\text { LIFT } \\
\text { (MAPLE } \\
\text { DW) }\end{array}$ & $\begin{array}{c}\text { US Naval Research } \\
\text { Laboratory, University of } \\
\text { North Carolina at Chapel } \\
\text { Hill, Georgia Institute of } \\
\text { Technology, Paul Scherrer } \\
\text { Institut, Laboratory for } \\
\text { Functional Polymers EMPA } \\
\text { Swiss Federal Laboratories } \\
\text { for Materials Testing and } \\
\text { Research Uberlandstrasse, } \\
\text { Hungarian Academy of } \\
\text { Sciences and University of } \\
\text { Szeged, National Institute } \\
\text { for Laser and Plasma and } \\
\text { Radiation Physics }\end{array}$ & $\begin{array}{l}\text { Patterning of viable B35 neuroblasts by } \\
\text { using triazene polymer intermediate } \\
\text { absorbing layer [149] }\end{array}$ & - \\
\hline
\end{tabular}




\begin{tabular}{|c|c|c|c|c|c|}
\hline & & & (Romania) & & \\
\hline $\begin{array}{c}\text { Custom-built } \\
\text { laser-based } \\
\text { bioprinter based } \\
\text { on ArF excimer } \\
\text { laser } \\
\end{array}$ & USA & $\begin{array}{l}\text { Modified } \\
\text { LIFT } \\
\text { (MAPLE } \\
\text { DW) }\end{array}$ & $\begin{array}{c}\text { US Naval Research } \\
\text { Laboratory and University } \\
\text { of North Carolina at Chapel } \\
\text { Hill }\end{array}$ & $\begin{array}{l}\text { Codeposition of hydroxyapatite and viable } \\
\text { MG } 63 \text { osteoblast-like cells [162] }\end{array}$ & - \\
\hline $\begin{array}{c}\text { Custom-built } \\
\text { laser-based } \\
\text { bioprinter based } \\
\text { on ArF excimer } \\
\text { laser }\end{array}$ & USA & $\begin{array}{l}\text { Modified } \\
\text { LIFT } \\
\text { (MAPLE } \\
\text { DW) }\end{array}$ & $\begin{array}{l}\text { Clemson University, } \\
\text { University of Florida, } \\
\text { Rensselaer Polytechnic } \\
\text { Institute and Tulane } \\
\text { University }\end{array}$ & $\begin{array}{c}\text { Laser fluence (energy) impact on yeast } \\
\text { [148] and human colon cancer cells } \\
\text { viability [155], alginate long tubes and } \\
\text { annular constructs fabrication [146], } \\
\text { alginate gelation impact on bioprinted NIH } \\
\text { 3T3 cell viability [163] and bifurcated } \\
\text { hollow tubular tissue (NIH 3T3 cells and } \\
\text { alginate) constructs [147] }\end{array}$ & - \\
\hline $\begin{array}{c}\text { Custom-built } \\
\text { laser-based } \\
\text { bioprinter based } \\
\text { on Nd:YAG laser }\end{array}$ & Germany & $\begin{array}{l}\text { Modified } \\
\text { LIFT } \\
\text { (LaBP) }\end{array}$ & $\begin{array}{l}\text { Laser Zentrum Hannover } \\
\text { e.V., Hannover Medical } \\
\text { School and Helmholtz } \\
\text { Institute of the RWTH } \\
\text { Aachen University }\end{array}$ & $\begin{array}{l}\text { 3D cell arrays comprising endothelial } \\
\text { colony forming cells (ECFCs) and adipose- } \\
\text { derived stem cells (ASCs) to study cell-to- } \\
\text { cell interactions in 3D environments [154], } \\
\text { skin tissue consisting of NIH-3T3 } \\
\text { fibroblasts, human keratinocyte cells and } \\
\text { collagen [156] and LaBP process impact on } \\
\text { adipogenic stem cell proliferation and } \\
\text { differentiation [153] }\end{array}$ & - \\
\hline $\begin{array}{c}\text { Custom-built } \\
\text { laser-based } \\
\text { bioprinter based } \\
\text { on KrF excimer } \\
\text { laser }\end{array}$ & $\begin{array}{l}\text { USA and } \\
\text { Hungary }\end{array}$ & $\begin{array}{l}\text { Modified } \\
\text { LIFT } \\
\text { (AFA- } \\
\text { LIFT) }\end{array}$ & $\begin{array}{l}\text { Hungarian Academy of } \\
\text { Sciences and University of } \\
\text { Szeged, University of } \\
\text { Szeged and US Naval } \\
\text { Research Laboratory }\end{array}$ & $\begin{array}{c}\text { AFA-LIFT impact on viability and } \\
\text { proliferation of bioprinted rat Schwann and } \\
\text { astroglial cells and pig lens epithelial cells } \\
\text { [152] }\end{array}$ & - \\
\hline
\end{tabular}

N/A - Information not available.

+ Capable of bioprinting one or more bioink at a time.

- Capable of bioprinting only one bioink at a time. 


\section{Limitations in Bioprinter Technologies}

Despite the improvements in bioprinting processes, the latest advancements in bioprinter technologies and the number of bioprinters recently introduced into the market, bioprinter technologies still exhibit a myriad of weaknesses, as outlined below. Such issues need to be addressed in order to make bioprinting a robust and affordable option for functional tissue fabrication and future clinical applications $[26]$.

\subsection{Limited Variety of the Commercially Available Bioprinters}

Despite the great progress in commercialization of bioprinter technologies, efforts have been largely limited to extrusion-based bioprinters with little attention to other bioprinting technologies such as LBB and DBB. Currently available extrusion-based bioprinters are quite similar to each other with only small variations in their functional and options such as advanced automation in cartridge replacement, automated loading and unloading capability of the bioink solution, and different software capabilities in terms of the motion system. Although a wide variety of inkjet-based printers are on the market, the majority of the inkjet printers are equipped with a small nozzle orifice opening, which is inconvenient for bioprinting mammalian cells with an average diameter of $20-25 \mu \mathrm{m}$. In addition to commercially available bioprinters, commercial 3D printers with open-source architecture is also helpful for researchers as some research groups prefer to customize their own bioprinters based on the final use. For example, Figure 4A shows a bioprinter at the Pennsylvania State University modified from a Solidoodle Workbench Apprentice, which is an open-source 3D printer. After modifying its FDM extruders into a pneumatically-driven EBB mechanism (Figure 4B), Pluronic F-127 hydrogel was printed on a thermallycontrolled table in the form of concentric cylinders (Figure 4C).

\subsection{Cartridge and Nozzle Design}

Current technologies have major issues with the cartridge and nozzle design as efficient loading and unloading a bioink solution, as well as the bioprinting, is vital for the success of a bioprinting process. Many of the cartridge technologies allow an operator to load the bioink before starting the bioprinting process. In general, cells held in a precursor hydrogel solution during a prolonged bioprinting period can 
result in poor viability. NovoGen $\mathrm{MMX}^{\mathrm{TM}}$ bioprinter overcame that issue by using a dispensing system with aspiration ability that allows the operator to load the solution into the pipette automatically using a back pressure mechanism. Although, this provides improved conditions for thermally-reversible materials (i.e., agarose) and some flexibility to the operator, clogging of the system can easily occur, thereby limiting this features use to lower viscosity biomaterials particularly during the aspiration process [164].

In addition to the automatic loading feature, nozzles used in droplet- and extrusion-based bioprinting should minimize cell damage while enabling higher resolution bioprinting with no wetting issues. Therefore, novel designs and material selection are essential to alleviate the applied shear stress. Improvements such as coating the nozzle with glass or ceramic [165] or development of a Taylor cone design instead of generally used straight tips [166] have been made. Innovative nozzle-free approaches, on the other hand, can overcome these issues. Only laser- [167] and acoustic-based [110] bioprinting technologies have nozzle-free configurations which facilitate the delivery of cells without exposing them to the shear stress.

\section{3. $\quad$ Size and Speed of Bioprinters}

The other limitation in bioprinter technologies is the size of bioprinters. In general, all bioprinters are designed to fabricate small structures in the sub centimeter scale range, yet the majority of the bioprinters employ very large working envelopes; this presents a major issue in the bioprinting of tissues, namely, maintenance of sterility during the bioprinting process. Conversely, there are bioprinters that are highly compact, but do not allow operator intervention whenever needed. As the technology transitions into a more robust and automated state, perhaps compact bioprinters can be integrated within bioreactor chambers with physiologically-relevant conditions [2].

The speed of bioprinting is another concern as the majority of EBB technologies try to cover a large area $\left(<1 \mathrm{~cm}^{2}\right)$ using a relatively small resolution, a procedure that can take hours when considering clinically-relevant dimensions and number of layers require in tissue constructs. This problem is amplified when using other bioprinting modalities, particularly LBB and DBB. Droplet-based bioprinting can circumvent that situation using multiple nozzles simultaneously; however, the smaller resolution still 
contributes substantially to the slow speed of bioprinting. Laser-based bioprinters are exceedingly slow as there is only a single laser beam tracing the region of interest; however, the recently developed microarray-based stereolithography systems provide more rapid platforms for bioprinting $[159,168]$. In addition, 3D printing of soft materials can be problematic; material such as hydrogel does not retain its shape and is subject to swelling, buckling, and bending over time. Thus, bioprinting time must be minimized to overcome these types of issues. One possible solution is to increase the number of printing arms using the Multi-Arm BioPrinter concept [22] or an array of nozzles attached on single arm [59] spaced at a distance close to the desired porosity with the ability to rotate along $\mathrm{z}$ axis to bioprint in $\mathrm{x}$ - and $\mathrm{y}$ - axis interchangeably.

\section{4. $\quad$ Limited Motion Capabilities}

Although modification of commercially-available inkjet printers has been implemented for bioprinting of biologics such as cells, DNA and growth factors, the motion system is limited to 1D or 2D depending on the technology. Therefore, additional motion stages are required to expand the range in 3D such as an integrated motorized table for the movement in z-axis. This can be rather expensive and difficult to engineer as it involves crosstalk between the existing motion system and the newly integrated one. The vast majority of the bioprinter technologies are limited to 3-axis motion, which will be difficult to operate as the technology transitions into operating rooms for in-situ bioprinting purposes [169]. Naturally occurring defects are irregular in shape and bioprinting within concave or non-planar defect surfaces may necessitate omnidirectional motion [169]. Thus, additional axes should be integrated to create more freedom and range of motion in the bioprinting process. BioAssemblyBot technology has the potential to overcome the current challenges associated with 3-axis bioprinters.

\subsection{Lack of Full Automation}

Another limitation of bioprinting technologies is the lack of full automation compared to conventional 3D printing processes such as material extrusion, powder bed fusion, vat photopolymerization and binder jetting [1]. One of the most important aspects of this drawback is the raw materials used in $3 \mathrm{D}$ printing technologies. For example, materials used in 3D printing processes 
including plastics, ceramics or metals are generally in solid-form before or after the 3D printing process and are highly stable. In contrast, biomaterials used in bioprinting processes are in gel or sol-gel form which cannot easily be fashioned in high resolution and cannot maintain the original printed shape. During the bioprinting process, the shape of the gel can easily collapse, swell or dehydrate. When the original path-plan is applied, problems can arise such as a printing level that is higher than the top surface of the construct or nozzle contact with the bioprinted material, all of which can result in a deformed construct. In this case, the bioprinting process needs to be restarted. This issue is amplified when bioprinting multiple bioink materials. Thus, vision-based process monitoring technologies have been used to detect the bioprinted construct height and inform the bioprinter in real time [116]. Despite these improved technologies, errors can multiply which ultimately can affect the overall quality of the bioprinted constructs.

Widely-used bioink materials, such as alginate and Pluronic F-127 have improved bioprintability properties, but do not promote cell growth and proliferation compared to ECM-based bioink materials [26]. Therefore, researchers acquiring commercially-available bioprinters do not employ these bioink materials. Most of the bioprinting efforts are devoted to the development and evaluation of new biomaterials. As a result, there is little standardization in bioprinting processes and nearly all bioprinters require a substantial amount of time for the user to optimize the process.

\subsection{High Cost of Bioprinting and Bioprinters}

One of the other limitations in bioprinting is the high cost of bioprinting and bioprinters. The bioprinting of living cells and following in-vitro culture are expensive endeavors. Particularly, the scaffold-free bioprinting approach [170] requires a substantial number of cells (on the order of 100 million cells) to generate a printable sample. Expansion of the cell culture requires a few months as well as considerable consumption of reagents [171]. In addition, the amount of bioink will be small; thus, the operator does not have much margin for error the bioprinting process. In short, bioprinting experimentation is a challenging, time consuming and expensive proposition. 
The cost of bioprinters is also another concern as the technology is still in its infancy [2]; however, as experienced with 3D printers, a decrease in the cost of bioprinters will most likely occur. Currently, the majority of the high quality, highly automated, high resolution bioprinters, lie in the price range of $\$ 150 \mathrm{k}$ to $\$ 200 \mathrm{k}$. Laser-based bioprinters are not commercially available, but the system can be assembled for more than a few hundred thousand dollars, depending on the capabilities. Inkjet-bioprinters can be inexpensive if a commercially-available inkjet printer is modified to a bioprinter but these

bioprinters do not support printing of live cells and lack 3D motion capability [76]. More expensive systems are commercially available for biological applications for $\$ 20-\$ 70 \mathrm{k}$ depending on the number of printheads and the resolution and automation of the system. A great number of startup companies have emerged to provide cost-effective and affordable bioprinters for researchers as well as industrial use. For example, affordable dual-head bioprinters with thermal and photo-crosslinking capabilities range from $\$ 5,000-10,000$; however, the quality, resolution and operability of these cost effective bioprinters are inferior to higher priced instruments. Nonetheless, these bioprinters provide unique opportunities as a training tool for researchers. The cost of a basic modified bioprinter, such as the Solidoodle Workbench Apprentice in Figure 4, can cost less than $\$ 500$ excluding the fluid dispensing system.

\subsection{Low Process Resolution}

The resolution of the bioprinting technology is currently a major impediment to bioprinting highdefinition constructs. Here, we discuss the resolution in the context of the smallest feature-size that can be bioprinted rather than the resolution of the motion system. As already discussed before, resolution of the motion system is considerably higher than that of the bioprinting process itself. Although highly accurate motion stages can be made, high resolution cannot be achieved in the bioprinted constructs due to constraints such as instability of hydrogel-based bioink materials and the limitations in the nozzle size due to clogging issues. In general, LBB and DBB processes have high resolution [14]; however, the most commonly used bioprinting modality, EBB, suffers from inferior resolution. In general, $100 \mu \mathrm{m}$ is the highest resolution range achieved in EBB [26]. Recent technology using bioplotting [172], on the other hand, allows for higher resolution, where a plotting medium with micro-particles acts like a Bingham 
plastic possessing solid-like behavior in static condition under low shear stress (plotting off) and viscous fluid-like behavior at higher shear stresses (plotting engaged). With this capability, higher resolution scaffolds have recently been bioprinted for developing branched vascular-constructs and complex heart constructs.

\subsection{Lack of Compatible Bioink Materials}

As native tissues and organs exhibit a heterocellular architecture, the bioink materials designed for tissue bioprinting should be suitable for growth and differentiation of cells into multiple lineages [173]; however, most of the currently available hydrogel-based bioink materials lack the native characteristics . Since each cell type requires the use of different bioink materials, optimization of bioink materials is challenging. In addition, the bioprintability of hydrogels depends on their shear-thinning property which increases when the viscosity of hydrogels increases. High viscosity favors mechanical and structural integrity as well as the formability of complex shapes; however, higher concentrations of hydrogels do not support cell viability and proliferation. In addition, hydrogels do not facilitate close cellto-cell contact when cells are immobilized and isolated from each other. Thus, scaffold-free bioink materials can be quite useful in the bioprinting of physiologically-relevant tissues, but the preparation, handling and cultivation of these constructs can be labor intensive and expensive [13].

\section{9. $\quad$ Progress in Bioprinting and Tissue Engineering Research}

Advances in bioprinter technologies depend upon progress in the areas of bioprinting, biomaterials and tissue engineering. More advanced bioprinting processes, which are practical for functional tissue fabrication, will support commercialization of these technologies. Although there is a wide spectrum of work that has been done in the context of bioprinting, most did not aim to generate functional tissues; only viability and short term functionality of cells were evaluated. In order to translate bioprinter technologies from bench to bedside, new bioprinting and tissue engineering approaches needs to be explored and discovered. Most of the work in bioprinting is limited to scaffold-based approaches with only a few works utilizing a scaffold-free approach to facilitate better tissue biomimicry; however, scaffold-free constructs lack mechanical integrity and rigidity [13]. Therefore, hybrid technologies are 
needed to generate mechanically supported scaffold-based structures along with physiologically-relevant scaffold-free tissue modules.

\subsection{Limited Clinical Translation}

The vast majority of efforts in bioprinting research has taken place in the area of basic science and a limited number of animal trials have been performed using bioprinted tissues. Pre-clinical experimentation is crucial for translation of the technology into clinics [26]. This will ultimately necessitate bioprinter technologies and bioprinted tissues and organs to be regulated by the Food and Drug Administration (FDA) that will require a long approval process. Food and Drug Administration currently does not have a classification for bioprinters and bioprinted tissues [66]. Because of this issue, the emerging bioprinting businesses prefer to produce instruments that are more readily commercialized such as tissues for drug testing and high-throughput screening. Another obstacle is the lack of scale-up tissues of clinically relevant sizes and function [169]. Current approaches are limited to small tissue and organ models due to lack of vascularization from arteries and veins down to capillaries. In addition, there exists ethical, social and regulatory concerns with the transplantation of bioprinted tissues and organs, issues with mechanical strength and stability of the tissues, long-term in-vivo functionality, immune rejection, engraftment and innervation with host tissues and organs.

\section{Future Outlook}

Despite the great progress in bioprinting technologies, there is vast room for improvement as well as new avenues for investigation. Although several commercial technologies are currently available for extrusion based bioprinting, limited products are available in DBB and LBB. Stereolithography and its modifications, which enable fabrication of geometrically complex high-definition tissue constructs, hold promise as translation of these technologies into the bioprinting market will be relatively easy. Only a few companies have commercialized inkjet bioprinting technology, therefore further investment can be considered in these areas to utilize the unique strengths of these technologies. Although extrusion-based technologies have been widely preferred for commercialization due to their flexibility and ability to create porous structures [174], further consideration and technological translational efforts should be extended to 
other bioprinting modalities. Such consideration could reduce cost, improve their practicality and increase the range of compatible bioink materials. As more bioink materials are introduced for different bioprinting modalities, it will be considerably easier for bioprinter builders to standardize and automate their bioprinters and bioprinting processes, which can enable rapid adoption of bioprinter technologies into non-bioprinting communities such as pharmaceutics, clinics and cancer research [175]. As currently available, laser-based bioprinting is challenging to execute and extrusion-based bioprinters require a significant learning curve; it is not trivial for an inexperienced user to practice these modalities. As inkjet bioprinters are highly automated, its translation into other fields such as pharmaceutics will occur sooner; some pharmaceutical companies have already implemented such platforms in their research [176].

For bioprinting scale-up tissues and organs, hybrid bioprinting technologies are desirable to easily integrate vascularization. Current modalities alone do not enable fabrication of blood vessels and the rest of the organs simultaneously but integrating multiple modalities (such as EBB for vascular network bioprinting using indirect bioprinting [26], and inkjet bioprinting for the rest of the parenchymal tissue) has been demonstrated. As the production of scaled-up tissues and organs necessitates prolonged bioprinting times, faster bioprinters are highly desirable. Alternatively, bioprinters with independent arms running in tandem can be another solution to increase the speed of bioprinting process. Such multiple-arm configuration can be further enhanced by adding extra motion capabilities such as expansion from 3-axes to 5-6 axes to bioprint on non-horizontal or non-planar surfaces. This is particularly vital for in-situ bioprinting when the technology translate into clinics [169].

In addition, online monitoring and inspection capabilities should be integrated into the bioprinter technologies as the quality of a bioprinted tissue construct is vital as the technology translates into the pharmaceutical market for tissue fabrication. In this regard, in-situ monitoring capabilities such as monitoring the structural integrity and geometric morphology of bioprinted tissue constructs using a machine vision-system and the biological quality of the constructs by monitoring the cellular activity through permittivity spectra of cells using a real-time non-destructive metrology tools will be quite beneficial [177]. 


\section{Conclusions}

Bioprinting has gained a great deal of attention and the technology has been adopted by a broad spectrum of application areas i.e., tissue engineering and regenerative medicine research, transplantation and clinics, pharmaceutics and high-throughput screening, cancer research, and cosmetology. This paper discussed the evolution of bioprinting technologies and presented an evaluation of commercially existing bioprinters in three different modalities including extrusion-, droplet- and laser-based bioprinting. Bioprinters currently suffer from several limitations such as low resolution, high cost and size, limited motion freedom and capacity, narrow range of compatible bioink materials, low-level of diversity in bioprinter modalities and non-functional end-products; however, the authors envision great progress in bioprinting field in the next decade as well as emerging enterprises that will further advance the state of the art in bioprinter technologies.

\section{Acknowledgement}

This work was supported by the US National Science Foundation CMMI Awards 1349716 and 1462232, Diabetes in Action Research and Education Foundation grant \# 426 and the Osteology Foundation Grant \# 15-042. The authors also acknowledge the support from the Engineering Science and Mechanics Department at Penn State University. The authors would like to thank Alyssa Sipos, Donna Sosnoski and Madhuri Dey from the Pennsylvania State University for their assistance with typesetting and Figure 4. The authors confirm that there are no known conflicts of interest associated with this publication and there has been no financial support for this work that could have influenced its outcome. 


\section{References}

[1] Y. Li, D. Li, B. Lu, D. Gao, J. Zhou, Current status of additive manufacturing for tissue engineering scaffold, Rapid Prototyp. J. 21 (6) (2015) 747-762.

[2] I.T. Ozbolat, Y. Yu, Bioprinting toward organ fabrication: challenges and future trends, IEEE Trans. Biomed. Eng. 60 (2013) 691-9.

[3] K. Kim, A. Yeatts, D. Dean, J.P. Fisher, Stereolithographic Bone Scaffold Design Parameters: Osteogenic Differentiation and Signal Expression, Tissue Eng. Part B Rev. 16 (2010) 523-539.

[4] J.M. Williams, A. Adewunmi, R.M. Schek, C.L. Flanagan, P.H. Krebsbach, S.E. Feinberg, S. J. Hollister, S. Das, Bone tissue engineering using polycaprolactone scaffolds fabricated via selective laser sintering, Biomaterials 26 (2005) 4817-27.

[5] Q. Hamid, J. Snyder, C. Wang, M. Timmer, J. Hammer, S. Guceri, W. Sun, Fabrication of threedimensional scaffolds using precision extrusion deposition with an assisted cooling device, Biofabrication 3 (2011) 34109.

[6] S. Tarafder, V.K. Balla, N.M. Davies, A. Bandyopadhyay, S. Bose, Microwave-sintered 3D printed tricalcium phosphate scaffolds for bone tissue engineering, J. Tissue Eng. Regen. Med. 7 (2013) 631-641.

[7] S. Skoog, P. Goering, R. Narayan, Stereolithography in tissue engineering, J. Mater. Sci. Mater. Med. 25 (2014) 845-856.

[8] D.S. Kohane, R. Langer, Polymeric Biomaterials in Tissue Engineering, Pediatr Res. 63 (2008) 487491.

[9] F.J. O’Brien, Biomaterials \& scaffolds for tissue engineering, Mater. Today 14 (2011) 88-95.

[10] O. Tsigkou, L.L. Hench, A.R. Boccaccini, J.M. Polak, M.M. Stevens, Enhanced differentiation and mineralization of human fetal osteoblasts on PDLLA containing Bioglass ${ }^{\circledR}$ composite films in the absence of osteogenic supplements, J. Biomed. Mater. Res. Part A 80A (2007) 837-851.

[11] V. Mouriño, J.P. Cattalini, A.R. Boccaccini, Metallic ions as therapeutic agents in tissue engineering scaffolds: an overview of their biological applications and strategies for new developments, J. R. Soc. Interface 9 (2012) 401-419.

[12] V. Mironov, R.P. Visconti, V. Kasyanov, G. Forgacs, C.J. Drake, R.R. Markwald, Organ printing: tissue spheroids as building blocks, Biomaterials 30 (2009) 2164-74.

[13] I.T. Ozbolat, Scaffold-based or Scaffold-free Bioprinting: Competing or Complementing Approaches?, J. Nanotechnol. Eng. Med. 6 (2015) 1-6.

[14] A.B. Dababneh, I.T. Ozbolat, Bioprinting Technology: A Current State-of-the-Art Review, J. Manuf. Sci. Eng. 136 (2014) 061016.

[15] I.T. Ozbolat, Special Issue on Three-Dimensional Bioprinting, J. Nanotechnol. Eng. Med. 6 (2015) 20301.

[16] R. Klebe, Cytoscribing: A method for micropositioning cells and the construction of two- and threedimensional synthetic tissues, Exp. Cell Res. 179 (1988) 362-373. 
[17] D.J. Odde, M.J. Renn, Laser-guided direct writing for applications in biotechnology, Trends Biotechnol. 17 (1999) 385-389.

[18] W.C. Wilson, T. Boland, Cell and organ printing 1: Protein and cell printers, Anat. Rec. Part A Discov. Mol. Cell. Evol. Biol. 272A (2003) 491-496.

[19] D.W. Hutmacher, M. Sittinger, M. V Risbud, Scaffold-based tissue engineering: rationale for computer-aided design and solid free-form fabrication systems, Trends Biotechnol. 22 (2004) 354-62.

[20] B. Rai, S.H. Teoh, D.W. Hutmacher, T. Cao, K.H. Ho, Novel PCL-based honeycomb scaffolds as drug delivery systems for rhBMP-2., Biomaterials 26 (2005) 3739-48.

[21] R.J. Narayan, Rapid Prototyping of Biomaterials, Elsevier, 2014.

[22] I.T. Ozbolat, H. Chen, Y. Yu, Development of "Multi-arm Bioprinter" for hybrid biofabrication of tissue engineering constructs, Robot. Comput. Integr. Manuf. 30 (2014) 295-304.

[23] Root Analysis, 3D Bioprinting Market 2014-2030, 2014.

[24] S. Knowlton, A. Joshi, B. Yenilmez, I.T. Ozbolat, C.K. Chua, A. Khademhosseini, S. Tasoglu, Advancing cancer research using 43, Int. J. Bioprinting 2 (2) (2016).

[25] I.T. Ozbolat, A. Khoda, Design of a New Parametric Path Plan for Additive Manufacturing of Hollow Porous Structures with Functionally Graded Materials, J. Comput. Inf. Sci. Eng. 14 (2014) 41005.

[26] I.T. Ozbolat, M. Hospodiuk, Current advances and future perspectives in extrusion-based bioprinting, Biomaterials 76 (2016) 321-43.

[27] A. Khoda, I.T. Ozbolat, B. Koc, Engineered tissue scaffolds with variational porous architecture, J. Biomech. Eng. 133 (2011) 011001.

[28] I.T. Ozbolat, B. Koc, Multi-function based modeling of 3D heterogeneous wound scaffolds for improved wound healing, Comput. Aided. Des. Appl. 8 (2011) 43-57.

[29] Y. Zhang, Y. Yu, A. Akkouch, A. Dababneh, F. Dolati, I.T. Ozbolat, In vitro study of directly bioprinted perfusable vasculature conduits, Biomater. Sci. 3 (2015) 134-143.

[30] Y. Zhang, Y. Yu, H. Chen, I.T. Ozbolat, Characterization of printable cellular micro-fluidic channels for tissue engineering., Biofabrication 5 (2013) 025004.

[31] Y. Yu, Y. Zhang, I.T. Ozbolat, A Hybrid Bioprinting Approach for Scale-Up Tissue Fabrication, J. Manuf. Sci. Eng. 136 (2014) 61013.

[32] F. Dolati, Y. Yu, Y. Zhang, A.M. De Jesus, E.A. Sander, I.T. Ozbolat, In vitro evaluation of carbonnanotube-reinforced bioprintable vascular conduits, Nanotechnology 25 (2014) 145101.

[33] R. Landers, U. Hübner, R. Schmelzeisen, R. Mülhaupt, Rapid prototyping of scaffolds derived from thermoreversible hydrogels and tailored for applications in tissue engineering, Biomaterials 23 (2002) 4437-4447. 
[34] Bioprinter Alpha |3Dynamic Systems Ltd. http://www.bioprintingsystems.com/bioprinteralpha.html, 2016 (accessed 07.18.16).

[35] Bioprinter Omega | 3Dynamic Systems Ltd. http://www.bioprintingsystems.com/bioprinteromega.html, 2016 (accessed 07.18.16).

[36] N.T. Ersumo, K.L. Spiller, A.B. Selection, Effects of hydrogel properties and extrusion parameters on 3D bioprinting, IEEE (2015) 25-26.

[37] BioBots, Biobots Inc. US. https://www.biobots.io/, 2016 (accessed 02.27.16).

[38] B. Duan, L.A. Hockaday, K.H. Kang, J.T. Butcher, 3D Bioprinting of heterogeneous aortic valve conduits with alginate/gelatin hydrogels, J. Biomed. Mater. Res. Part A 101A (2013) 1255-1264.

[39] D.L. Cohen, J.I. Lipton, L.J. Bonassar, H. Lipson, Additive manufacturing for in situ repair of osteochondral defects, Biofabrication 2 (2010) 035004.

[40] M.S. Mannoor, Z. Jiang, T. James, Y.L. Kong, K.A. Malatesta, W.O. Soboyejo, N. Verma, D.H. Gracias, M.C. McAlpine, 3D Printed Bionic Ears, Nano Lett. 13 (2013) 2634-2639.

[41] E. Malone, H. Lipson, Fab@Home: the personal desktop fabricator kitnull, Rapid Prototyp. J. 13 (2007) 245-255.

[42] Seraph Robotics. http://www.scientist3d.com/, 2016 (accessed 02.27.16).

[43] Cellink. http://www.cellink3d.com/, 2016 (accessed 02.27.16).

[44] F. Zou, N. Zhao, X. Fu, J. Diao, Y. Ma, X. Cao, S. Wan, S. Zhong, Y. Wang, Enhanced osteogenic differentiation and biomineralization in mouse mesenchymal stromal cells on a $\beta$-TCP robocast scaffold modified with collagen nanofibers, RSC Adv. 6 (2016) 23588-23598.

[45] L. Wang, M. Xu, L. Zhang, Q. Zhou, L. Luo, Automated quantitative assessment of threedimensional bioprinted hydrogel scaffolds using optical coherence tomography, Biomed. Opt. Express. 7 (2016) 894.

[46] V.H. Bodrum, L. Aydin, D.S. Kucuk, H. Kenar, Design and construction of a 3D Bioprinter for Bioprinting of tissues and organs, Deneysel ve Klinik Arastirmalar Merkezi, (2015) 153-157.

[47] Regemat3D. http://www.regemat3d.com/, 2016 (accessed 07.18.16).

[48] Advanced Solutions Life Sciences. http://www.lifesciences.solutions/, 2016 (accessed 07.18.16).

[49] N.E. Fedorovich, J.R. De Wijn, A.J. Verbout, J. Alblas, W.J.A. Dhert, Three-Dimensional Fiber Deposition of Cell-Laden, Viable, Patterned Constructs for Bone Tissue Printing, Tissue Eng. Part A 14 (2008) 127-133.

[50] K.B. Chien, E. Makridakis, R.N. Shah, Three Dimensional Printing of Soy Protein Scaffolds for Tissue Regeneration, Tissue Eng. Part C Methods 19 (2012) 121026142624002.

[51] EnvisionTEC. http://envisiontec.com/, 2016 (accessed 02.27.16). 
[52] E. Golez, E. Barruet, E. Hsiao, K. Schepers, S. Presnell, D. Nguyen, K. Retting, Three-dimensional (3D) bone tissues derived from stem cells as a novel model for mineralization, Stem Cell Meeting on the Mesa, La Jolla, CA 2014 Poster no. 23.

[53] J.B. Robbins, C.M.O. Neill, V. Gorgen, S.C. Presnell, B.R. Shepherd, Bioprinted three-dimensional (3D) human liver constructs provide a model for interrogating liver biology, The American Society of Biology (2013).

[54] S.M. King, V. Gorgen, S.C. Presnell, D.G. Nguyen, B.R. Shepherd, Development of 3D bioprinted human breast cancer for in vitro screening of therapeutics targeted against cancer progression, American Society of Biology, New Orleans, LA (2013).

[55] L.E. Bertassoni, M. Cecconi, V. Manoharan, M. Nikkhah, J. Hjortnaes, A.L. Cristino, G. Barabaschi, D. Demarchi, M.R. Dokmeci, Y. Yang, A. Khademhosseini, Hydrogel bioprinted microchannel networks for vascularization of tissue engineering constructs, Lab Chip 14 (2014) 2202-2211.

[56] C.M. Smith, A. Stone, R.L. Stewart, M.W. Simpkins, A.M. Kachurin, W.L. Warren, S.K. Williams, Three-Dimensional BioAssembly Tool for Generating Viable Tissue-Engineered Constructs, Tissue Eng. 10 (2004) 1566-1576.

[57] Bio3D Technologies - Printing \& Shaping the Future. http://bio3d.tech/, 2016 (accessed 07.18.16).

[58] K. Markstedt, A. Mantas, I. Tournier, H. Martínez Ávila, D. Hägg, P. Gatenholm, 3D Bioprinting Human Chondrocytes with Nanocellulose-Alginate Bioink for Cartilage Tissue Engineering Applications, Biomacromolecules 16 (2015) 1489-1496.

[59] L. Horváth, Y. Umehara, C. Jud, F. Blank, A. Petri-Fink, B. Rothen-Rutishauser, Engineering an in vitro air-blood barrier by 3D bioprinting, Sci. Rep. 5 (2015) 7974.

[60] 3Dynamic Systems Ltd | Bioprinting | Alpha \& Omega Bioprinters. http://www.bioprintingsystems.com/, 2016 (accessed 07.18.16).

[61] D.L. Cohen, W. Lo, A. Tsavaris, D. Peng, H. Lipson, L.J. Bonassar, Increased Mixing Improves Hydrogel Homogeneity and Quality of Three-Dimensional Printed Constructs, Tissue Eng. Part C Methods 17 (2010) 239-248.

[62] B. Duan, E. Kapetanovic, L.A. Hockaday, J.T. Butcher, Three-dimensional printed trileaflet valve conduits using biological hydrogels and human valve interstitial cells, Acta Biomater. 10 (2014) 1836-46.

[63] Regenovo Biotechnology Co. Ltd. http://regenovo.com/english/, 2016 (accessed 02.27.16).

[64] P. Sheshadri, R.A. Shirwaiker, Characterization of Material-Process-Structure Interactions in the 3D Bioplotting of Polycaprolactone, 3D Print. Addit. Manuf. 2 (2015) 20-31.

[65] A. Pfister, R. Landers, A. Laib, U. Hübner, R. Schmelzeisen, R. Mülhaupt, Biofunctional rapid prototyping for tissue-engineering applications: 3D bioplotting versus 3D printing, J. Polym. Sci. Part A Polym. Chem. 42 (2004) 624-638.

[66] S.M. King, S.C. Presnell, D.G. Nguyen, Abstract 2034: Development of 3D bioprinted human breast cancer for in vitro drug screening, Cancer Res. 74 (2014) 2034. 
[67] K. Roskos, I. Stuiver, S. Pentoney, S. Presnell, Essentials of 3D Biofabrication and Translation, Elsevier, 2015.

[68] C. Norotte, F.S. Marga, L.E. Niklason, G. Forgacs, Scaffold-free vascular tissue engineering using bioprinting, Biomaterials 30 (2009) 5910-5917.

[69] K. Jakab, C. Norotte, B. Damon, F. Marga, A. Neagu, C.L. Besch-Williford, A. Kachurin, K.H. Church, H. Park, V. Mironov, R. Markwald, G. Vunjak-Novakovic, G. Forgacs, Tissue engineering by self-assembly of cells printed into topologically defined structures, Tissue Eng. Part A. 14 (2008) 413-21.

[70] nScrypt | 3D conformal dispensing systems \& laser micro printing. http://nscrypt.com/, 2016 (accessed 07.18.16).

[71] RegenHU biosystems architects. http://www.regenhu.com/, 2016 (accessed 02.27.16).

[72] W.L. Ng, W.Y. Yeong, M.W. Naing, Polyelectrolyte gelatin-chitosan hydrogel optimized for 3D bioprinting in skin tissue engineering, International Journal of Bioprinting 2 (1) (2016).

[73] E.Y.S. Tan, W.Y. Yeong, Concentric bioprinting of alginate-based tubular constructs using multinozzle extrusion-based technique, Int. J. Bioprinting 1 (2015) 49-56.

[74] T. Xu, K.W. Binder, M.Z. Albanna, D. Dice, W. Zhao, J.J. Yoo, A. Atala, Hybrid printing of mechanically and biologically improved constructs for cartilage tissue engineering applications, Biofabrication 5 (2013) 015001.

[75] H. Gudapati, M. Dey, I. Ozbolat, A comprehensive review on droplet-based bioprinting: Past, present and future, Biomaterials 102 (2016) 20-42.

[76] T. Xu, J. Jin, C. Gregory, J.J. Hickman, T. Boland, Inkjet printing of viable mammalian cells, Biomaterials 26 (2005) 93-99.

[77] T. Xu, C.A. Gregory, P. Molnar, X. Cui, S. Jalota, S.B. Bhaduri, T. Boland, Viability and electrophysiology of neural cell structures generated by the inkjet printing method, Biomaterials 27 (2006) 3580-8.

[78] T. Boland, X. Tao, B.J. Damon, B. Manley, P. Kesari, S. Jalota, S. Bhaduri, Drop-on-demand printing of cells and materials for designer tissue constructs, Mater. Sci. Eng. C. 27 (2007) 372-376.

[79] T. Xu, C. Baicu, M. Aho, M. Zile, T. Boland, Fabrication and characterization of bio-engineered cardiac pseudo tissues, Biofabrication 1 (2009) 035001.

[80] Y. Nishiyama, M. Nakamura, C. Henmi, K. Yamaguchi, S. Mochizuki, H. Nakagawa, K. Takiura, Development of a Three-Dimensional Bioprinter: Construction of Cell Supporting Structures Using Hydrogel and State-Of-The-Art Inkjet Technology, J. Biomech. Eng. 131 (2008) 35001.

[81] W.S. Choi, D. Ha, S. Park, T. Kim, Synthetic multicellular cell-to-cell communication in inkjet printed bacterial cell systems, Biomaterials 32 (2011) 2500-2507.

[82] C.J. Ferris, K.J. Gilmore, S. Beirne, D. McCallum, G.G. Wallace, M. in het Panhuis, Bio-ink for ondemand printing of living cells, Biomater. Sci. 1 (2013) 224-230. 
[83] S. Yamaguchi, A. Ueno, Y. Akiyama, K. Morishima, Cell patterning through inkjet printing of one cell per droplet., Biofabrication 4 (2012) 045005.

[84] R. Suntivich, I. Drachuk, R. Calabrese, D.L. Kaplan, V. V. Tsukruk, Inkjet printing of silk nest arrays for cell hosting, Biomacromolecules 15 (2014) 1428-35.

[85] C. Xu, W. Chai, Y. Huang, R.R. Markwald, Scaffold-free inkjet printing of three-dimensional zigzag cellular tubes, Biotechnol. Bioeng. 109 (2012) 3152-3160.

[86] K. Christensen, C. Xu, W. Chai, Z. Zhang, J. Fu, Y. Huang, Freeform inkjet printing of cellular structures with bifurcations, Biotechnol. Bioeng. 112 (2015) 1047-1055.

[87] N.F. Morrison, O.G. Harlen, Viscoelasticity in inkjet printing, Rheol. Acta. 49 (2010) 619-632.

[88] F. Xu, S.J. Moon, A. E. Emre, E.S. Turali, Y.S. Song, S. A. Hacking, J Nagatomi, U. Demirci, A droplet-based building block approach for bladder smooth muscle cell (SMC) proliferation,

Biofabrication 2 (2010) 014105.

[89] S. Moon, S.K. Hasan, Y.S. Song, F. Xu, H.O. Keles, F. Manzur, S. Mikkilinen, J.W. Hong, J. Nagatomi, E. Haeggstrom, A. Khademhosseini, U. Demirci, Layer by layer three-dimensional tissue epitaxy by cell-laden hydrogel droplets, Tissue Eng. Part C. Methods 16 (2010) 157-66.

[90] F. Xu, J. Celli, I. Rizvi, S. Moon, T. Hasan, U. Demirci, A three-dimensional in vitro ovarian cancer coculture model using a high-throughput cell patterning platform, Biotechnol. J. 6 (2011) 204-212.

[91] U.A. Gurkan, R. El Assal, S.E. Yildiz, Y. Sung, A.J. Trachtenberg, W.P. Kuo, U. Demirci, Engineering Anisotropic Biomimetic Fibrocartilage Microenvironment by Bioprinting Mesenchymal Stem Cells in Nanoliter Gel Droplets, Mol. Pharm. 11 (2014) 2151-2159.

[92] W. Lee, J.C. Debasitis, V.K. Lee, J.H. Lee, K. Fischer, K. Edminster, J.K. Park, S.S. Yoo, Multilayered culture of human skin fibroblasts and keratinocytes through three-dimensional freeform fabrication, Biomaterials 30 (2009) 1587-1595.

[93] Y.B. Lee, S. Polio, W. Lee, G. Dai, L. Menon, R.S. Carroll, S.S. Yoo, Bio-printing of collagen and VEGF-releasing fibrin gel scaffolds for neural stem cell culture, Exp. Neurol. 223 (2010) 645-52.

[94] V. Lee, A. Lanzi, H. Ngo, S.-S. Yoo, P. Vincent, G. Dai, Generation of Multi-scale Vascular Network System Within 3D Hydrogel Using 3D Bio-printing Technology, Cell. Mol. Bioeng. 7 (2014) 460-472.

[95] A. Faulkner-Jones, S. Greenhough, J. A King, J. Gardner, A. Courtney, W. Shu, Development of a valve-based cell printer for the formation of human embryonic stem cell spheroid aggregates, Biofabrication 5 (2013) 015013.

[96] A. Faulkner-Jones, C. Fyfe, D. Cornelissen, J. Gardner, J. King, A. Courtney, W. Shu, Bioprinting of human pluripotent stem cells and their directed differentiation into hepatocyte-like cells for the generation of mini-livers in 3D, Biofabrication 7 (2015) 044102.

[97] C. Li, A. Faulkner-Jones, A.R. Dun, J. Jin, P. Chen, Y. Xing, Z. Yang, Z. Li, W. Shu, D. Liu, R.R. Duncan, Rapid formation of a supramolecular polypeptide-DNA hydrogel for in situ three-dimensional multilayer bioprinting, Angew. Chem. Int. Ed. Engl. 54 (2015) 3957-61. 
[98] S. Tasoglu, U. Demirci, Bioprinting for stem cell research, Trends Biotechnol. 31 (2013) 10-19.

[99] S.N. Jayasinghe, A.N. Qureshi, P.A.M. Eagles, Electrohydrodynamic jet processing: an advanced electric-field-driven jetting phenomenon for processing living cells, Small 2 (2006) 216-9.

[100] S.N. Jayasinghe, M.J. Edirisinghe, Electrostatic atomisation of a ceramic suspension, J. Eur. Ceram. Soc. 24 (2004) 2203-2213.

[101] S. Jayasinghe, M. Edirisinghe, T. De Wilde, A novel ceramic printing technique based on electrostatic atomization of a suspension, Mater. Res. Innov. 6 (2002) 92-95.

[102] P.A. Eagles, A.N. Qureshi, S.N. Jayasinghe, Electrohydrodynamic jetting of mouse neuronal cells, Biochem. J. 394 (2006) 375-8.

[103] V.L. Workman, L.B. Tezera, P.T. Elkington, S.N. Jayasinghe, Controlled Generation of Microspheres Incorporating Extracellular Matrix Fibrils for Three-Dimensional Cell Culture, Adv. Funct. Mater. 24 (2014) 2648-2657.

[104] J. Xie, C.-H. Wang, Electrospray in the dripping mode for cell microencapsulation, J. Colloid Interface Sci. 312 (2007) 247-255.

[105] H.S. Kim, D.Y. Lee, J.H. Park, J.H. Kim, J.H. Hwang, H.I. Jung, Optimization of Electrohydrodynamic Writing Technique To Print Collagen, Exp. Tech. 31 (2007) 15-19.

[106] M.J. Poellmann, K.L. Barton, S. Mishra, A.J.W. Johnson, Patterned Hydrogel Substrates for Cell Culture with Electrohydrodynamic Jet Printing, Macromol. Biosci. 11 (2011) 1164-1168.

[107] M.S. Onses, E. Sutanto, P.M. Ferreira, A.G. Alleyne, J. A. Rogers, Mechanisms, capabilities, and applications of high-resolution electrohydrodynamic jet printing, Small 11 (2015) 4237-66.

[108] E. Sutanto, K. Shigeta, Y.K. Kim, P.G. Graf, D.J. Hoelzle, K.L. Barton, A. G. Alleyne, P. M. Ferreira, J.A. Rogers, A multimaterial electrohydrodynamic jet (E-jet) printing system, J. Micromechanics Microengineering 22 (2012) 045008.

[109] L. Gasperini, D. Maniglio, A. Motta, C. Migliaresi, An Electrohydrodynamic Bioprinter for Alginate Hydrogels Containing Living Cells, Tissue Eng. Part C Methods 21 (2015) 123-132.

[110] U. Demirci, G. Montesano, Single cell epitaxy by acoustic picolitre droplets, Lab Chip 7 (2007) $1139-1145$.

[111] Y. Fang, J.P. Frampton, S. Raghavan, R. Sabahi-Kaviani, G. Luker, C.X. Deng, S. Takayama, Rapid Generation of Multiplexed Cell Cocultures Using Acoustic Droplet Ejection Followed by Aqueous Two-Phase Exclusion Patterning, Tissue Eng. Part C Methods 18 (2012) 647-657.

[112] Microarray printing, biochip spotting on Autodrop positioning systems. http://www.microdrop.com/autodrop-platform-69.html, 2016 (accessed 07.18.16).

[113] B. Derby, Inkjet printing of functional and structural materials: fluid property requirements, feature stability, and resolution, Annu. Rev. Mater. Res. 40 (2010) 395-414.

[114] H. Wijshoff, The dynamics of the piezo inkjet printhead operation, Phys. Rep. 491 (2010) 77-177. 
[115] M. Singh, H.M. Haverinen, P. Dhagat, G.E. Jabbour, Inkjet printing-process and its applications, Adv. Mater. 22 (2010) 673-685.

[116] MicroFab Technologies Inc., Complete Systems. http://www.microfab.com/complete-systems, 2016 (accessed 04.03.16).

[117] Fujifilm Holdings America Corporation, Dimatix Revolutionizes Materials Deposition with Industry's First Low-Cost, Cartridge-Based Ink Jet Printing System. http://www.fujifilmusa.com/press/news/display_news?newsID=880138, 2005 (accessed 09.10.2016).

[118] M. Matsusaki, K. Sakaue, K. Kadowaki, M. Akashi, Three-dimensional human tissue chips fabricated by rapid and automatic inkjet cell printing, Adv. Healthc. Mater. 2 (2013) 534-539.

[119] P.G. Campbell, E.D. Miller, G.W. Fisher, L.M. Walker, L.E. Weiss, Engineered spatial patterns of FGF-2 immobilized on fibrin direct cell organization, Biomaterials 26 (2005) 6762-70.

[120] E.D. Miller, G.W. Fisher, L.E. Weiss, L.M. Walker, P.G. Campbell, Dose-dependent cell growth in response to concentration modulated patterns of FGF-2 printed on fibrin, Biomaterials 27 (2006) 221321.

[121] J.A. Phillippi, E. Miller, L. Weiss, J. Huard, A. Waggoner, P. Campbell, Microenvironments Engineered by Inkjet Bioprinting Spatially Direct Adult Stem Cells Toward Muscle- and Bone-Like Subpopulations, Stem Cells 26 (2008) 127-134.

[122] E. Cheng, A. Ahmadi, K.C. Cheung, Investigation of the Hydrodynamics of Suspended Cells for Reliable Inkjet Cell Printing, American Society of Mechanical Engineers (2014) 1-8.

[123] E. Roth, T. Xu, M. Das, C. Gregory, J. Hickman, T. Boland, Inkjet printing for high-throughput cell patterning, Biomaterials 25 (2004) 3707-3715.

[124] X. Cui, T. Boland, Human microvasculature fabrication using thermal inkjet printing technology, Biomaterials 30 (2009) 6221-6227.

[125] M. Yanez, J. Rincon, A. Dones, C. De Maria, R. Gonzales, T. Boland, In Vivo Assessment of Printed Microvasculature in a Bilayer Skin Graft to Treat Full-Thickness Wounds, Tissue Eng. Part A 21 (2014) 224-233.

[126] T. Xu, H. Kincaid, A. Atala, J.J. Yoo, High-Throughput Production of Single-Cell Microparticles Using an Inkjet Printing Technology, J. Manuf. Sci. Eng. 130 (2008) 021017.

[127] T. Xu, W. Zhao, J.M. Zhu, M.Z. Albanna, J.J. Yoo, A. Atala, Complex heterogeneous tissue constructs containing multiple cell types prepared by inkjet printing technology, Biomaterials 34 (2013) $130-139$.

[128] X. Cui, K. Breitenkamp, M.G. Finn, M. Lotz, D.D. D’Lima, Direct Human Cartilage Repair Using Three-Dimensional Bioprinting Technology, Tissue Eng. Part A. 18 (2012) 1304-1312.

[129] X. Cui, K. Breitenkamp, M. Lotz, D. D'Lima, Synergistic action of fibroblast growth factor-2 and transforming growth factor-beta1 enhances bioprinted human neocartilage formation, Biotechnol. Bioeng. 109 (2012) 2357-2368. 
[130] G. Gao, T. Yonezawa, K. Hubbell, G. Dai, X. Cui, Inkjet-bioprinted acrylated peptides and PEG hydrogel with human mesenchymal stem cells promote robust bone and cartilage formation with minimal printhead clogging, Biotechnol. J. 10 (2015) 1568-77.

[131] G. Gao, A.F. Schilling, T. Yonezawa, J. Wang, G. Dai, X. Cui, Bioactive nanoparticles stimulate bone tissue formation in bioprinted three-dimensional scaffold and human mesenchymal stem cells, Biotechnol. J. 9 (2014) 1304-1311.

[132] J.I. Rodríguez-Dévora, B. Zhang, D. Reyna, Z. Shi, T. Xu, High throughput miniature drugscreening platform using bioprinting technology, Biofabrication 4 (2012) 035001.

[133] A. Yusof, H. Keegan, C.D. Spillane, O.M. Sheils, C.M. Martin, J.J. O’Leary, R. Zengerle, P. Koltay, Inkjet-like printing of single-cells, Lab Chip 11 (2011) 2447-54.

[134] S.N. Jayasinghe, A. Townsend-Nicholson, Stable electric-field driven cone-jetting of concentrated biosuspensions, Lab Chip 6 (2006) 1086-1090.

[135] N. Mongkoldhumrongkul, S. Best, E. Aarons, S.N. Jayasinghe, Bio-electrospraying whole human blood: analysing cellular viability at a molecular level, J. Tissue Eng. Regen. Med. 3 (2009) 562-6.

[136] L. Gasperini, D. Maniglio, C. Migliaresi, Microencapsulation of cells in alginate through an electrohydrodynamic process, J. Bioact. Compat. Polym. 28 (2013) 413-425.

[137] W. Lee, J. Pinckney, V. Lee, J.-H. Lee, K. Fischer, S. Polio, J.-K. Park, S.-S, Yoo, Threedimensional bioprinting of rat embryonic neural cells, Neuroreport 20 (2009) 798-803.

[138] D.J. Odde, M.J. Renn, Laser-guided direct writing of living cells, Biotechnol. Bioeng. 67 (2000) 312-8.

[139] B.R. Ringeisen, P.K. Wu, H. Kim, A. Pique, R.Y.C. Auyeung, H.D. Young, D.B. Chrisey, D.B. Krizman, Picoliter-Scale Protein Microarrays by Laser Direct Write, Biotechnol. Prog. 18 (2002) 11261129.

[140] B.R. Ringeisen, H. Kim, J. A. Barron, D.B. Krizman, D.B. Chrisey, S. Jackman, R.Y.C. Auyeung, B.J. Spargo, Laser printing of pluripotent embryonal carcinoma cells, Tissue Eng. 10 (2004) 483-491.

[141] M. Renn, R. Pastel, H. Lewandowski, Laser Guidance and Trapping of Mesoscale Particles in Hollow-Core Optical Fibers, Phys. Rev. Lett. 82 (1999) 1574-1577.

[142] J. Xu, S.A. Grant, R.L. Pastel, Laser-guided direct writing: A novel method to deposit biomolecules for biosensors arrays, IEEE Trans. Biomed. Eng. 50 (2003) 126-128.

[143] Y. Nahmias, R.E. Schwartz, C.M. Verfaillie, D.J. Odde, Laser-guided direct writing for threedimensional tissue engineering, Biotechnol. Bioeng. 92 (2005) 129-136.

[144] B.R. Ringeisen, C.M. Othon, J.A. Barron, D. Young, B.J. Spargo, Jet-based methods to print living cells, Biotechnol. J. 1 (2006) 930-948.

[145] Y. Lin, Y. Huang, Laser-assisted fabrication of highly viscous alginate microsphere, J. Appl. Phys. 109 (2011). 
[146] J. Yan, Y. Huang, D.B. Chrisey, Laser-assisted printing of alginate long tubes and annular constructs, Biofabrication 5 (2013) 015002.

[147] R. Xiong, Z. Zhang, W. Chai, Y. Huang, D.B. Chrisey, Freeform drop-on-demand laser printing of 3D alginate and cellular constructs, Biofabrication 7 (2015) 045011.

[148] Y. Lin, Y. Huang, G. Wang, T.R.J. Tzeng, D.B. Chrisey, Effect of laser fluence on yeast cell viability in laser-assisted cell transfer, J. Appl. Phys. 106 (2009).

[149] A. Doraiswamy, R.J. Narayan, T. Lippert, L. Urech, A. Wokaun, M. Nagel, B. Hopp, M. Dinescu, R. Modi, R.C.Y. Auyeung, D.B. Chrisey, Excimer laser forward transfer of mammalian cells using a novel triazene absorbing layer, Appl. Surf. Sci. 252 (2006) 4743-4747.

[150] J.A. Barron, P. Wu, H.D. Ladouceur, B.R. Ringeisen, Biological laser printing: A novel technique for creating heterogeneous 3-dimensional cell patterns, Biomed. Microdevices 6 (2004) 139-147.

[151] J.A. Barron, B.J. Spargo, B.R. Ringeisen, Biological laser printing of three dimensional cellular structures, Appl. Phys. A. 79 (2004) 1027-1030.

[152] B. Hopp, T. Smausz, N. Kresz, N. Barna, Z. Bor, L. Kolozsvári, D.B. Chrisey, A. Szabó, A. Nógrádi, Survival and proliferative ability of various living cell types after laser-induced forward transfer, Tissue Eng. 11 (11-12.) 1817-23.

[153] M. Gruene, M. Pflaum, a Deiwick, L. Koch, S. Schlie, C. Unger, M. Wilhelmi, A. Haverich, B.N. Chichkov, Adipogenic differentiation of laser-printed 3D tissue grafts consisting of human adiposederived stem cells, Biofabrication 3 (2011) 015005.

[154] M. Gruene, M. Pflaum, C. Hess, S. Diamantouros, S. Schlie, A. Deiwick, L. Koch, M. Wilhelmi, S. Jockenhoevel, A. Haverich, B. Chichkov, Laser Printing of Three-Dimensional Multicellular Arrays for Studies of Cell-Cell and Cell-Environment Interactions, Tissue Eng. Part C Methods 17 (2011) 973-982.

[155] Y. Lin, G. Huang, Y. Huang, T.-R.J. Tzeng, D. Chrisey, Effect of laser fluence in laser-assisted direct writing of human colon cancer cell, Rapid Prototyp. J. 16 (2010) 202-208.

[156] L. Koch, A. Deiwick, S. Schlie, S. Michael, M. Gruene, V. Coger, D. Zychlinski, A. Schambach, K. Reimers, P.M. Vogt, B. Chichkov, Skin tissue generation by laser cell printing, Biotechnol. Bioeng. 109 (2012) 1855-1863.

[157] L. Koch, S. Kuhn, H. Sorg, M. Gruene, S. Schlie, R. Gaebel, B. Polchow, K. Reimers, S. Stoelting, N. Ma, P.M. Vogt, G. Steinhoff, B. Chichkov, Laser printing of skin cells and human stem cells, Tissue Eng. Part C. Methods. 16 (2010) 847-854.

[158] A. Skardal, A. Atala, Biomaterials for integration with 3-D bioprinting, Ann. Biomed. Eng. 43 (2015) 730-46.

[159] K.C. Hribar, P. Soman, J. Warner, P. Chung, S. Chen, Light-assisted direct-write of 3D functional biomaterials, Lab Chip 14 (2014) 268-275.

[160] J.A. Barron, B.R. Ringeisen, H. Kim, B.J. Spargo, D.B. Chrisey, Application of laser printing to mammalian cells, Thin Solid Films 453-454 (2004) 383-387. 
[161] J.A. Barron, D.B. Krizman, B.R. Ringeisen, Laser printing of single cells: Statistical analysis, cell viability, and stress, Ann. Biomed. Eng. 33 (2005) 121-130.

[162] A. Doraiswamy, R.J. Narayan, M.L. Harris, S.B. Qadri, R. Modi, D.B. Chrisey, Laser microfabrication of hydroxyapatite-osteoblast-like cell composites, J. Biomed. Mater. Res. A. 80 (2007) 635-43.

[163] H. Gudapati, J. Yan, Y. Huang, D.B. Chrisey, Alginate gelation-induced cell death during laserassisted cell printing, Biofabrication 6 (2014) 035022.

[164] C. Kucukgul, S.B. Ozler, I. Inci, E. Karakas, S. Irmak, D. Gozuacik, A. Taralp, B.Koc, 3D bioprinting of biomimetic aortic vascular constructs with self-supporting cells, Biotechnol. Bioeng. 112 (2015) 811-21.

[165] D.A. Bruzewicz, M. Reches, G.M. Whitesides, Low-Cost Printing of PDMS Barriers to Define Microchannels in Paper, Changes 29 (2012) 997-1003.

[166] J. Franco, P. Hunger, M.E. Launey, A.P. Tomsia, E. Saiz, Direct-Write Assembly of Calcium Phosphate Scaffolds Using a Water-Based Hydrogel, Acta biomaterialia 6 (1) (2011) 218-228.

[167] R. Xiong, Z. Zhang, Y. Huang, Identification of optimal printing conditions for laser printing of alginate tubular constructs, J. Manuf. Process 20 (2015) 450-455.

[168] A.P. Zhang, X. Qu, P. Soman, K.C. Hribar, J.W. Lee, S. Chen, S. He, Rapid Fabrication of Complex 3D Extracellular Microenvironments by Dynamic Optical Projection Stereolithography, Adv. Mater. 24 (2012) 4266-4270.

[169] I.T. Ozbolat, Bioprinting scale-up tissue and organ constructs for transplantation., Trends Biotechnol. 33 (2015) 395-400.

[170] Y. Yu, K.K. Moncal, J. Li, W. Peng, I. Rivero, J.A. Martin, I.T. Ozbolat, Three-dimensional bioprinting using self-assembling scalable scaffold-free "tissue strands" as a new bioink, Sci. Rep. 6 (2016) 28714.

[171] A. Akkouch, Y. Yu, I.T. Ozbolat, Microfabrication of scaffold-free tissue strands for threedimensional tissue engineering, Biofabrication 7 (2015) 31002.

[172] T.J. Hinton, Q. Jallerat, R.N. Palchesko, J.H. Park, M.S. Grodzicki, H.-J. Shue, M.H. Ramadan, A.R. Hudson, A.W. Feinberg, Three-dimensional printing of complex biological structures by freeform reversible embedding of suspended hydrogels, Sci. Adv. 1 (2015).

[173] E.D.F. Ker, B. Chu, J. Phillippi, B. Gharaibeh, J. Huard, L.E. Weiss, P.G. Campbell, Engineering spatial control of multiple differentiation fates within a stem cell population, Biomaterials 32 (2011) 3413-3422.

[174] A.K.M. Khoda, I.T. Ozbolat, B. Koc, Designing heterogeneous porous tissue scaffolds for additive manufacturing processes, CAD Comput. Aided Des. 45 (2013) 1507-1523.

[175] I.T. Ozbolat, W. Peng, V. Ozbolat, Application areas of 3D bioprinting, Drug Discov. Today (2016). 
[176] W. Peng, D. Unutmaz, I.T. Ozbolat, Bioprinting towards Physiologically Relevant Tissue Models for Pharmaceutics, Trends Biotechnol. (2016).

[177] N. Pavillon, A.J. Hobro, N.I. Smith, Cell optical density and molecular composition revealed by simultaneous multimodal label-free imaging, Biophys. J. 105 (2013) 1123-32. 


\section{Figure Captions}

Figure 1. Components of an extrusion-based bioprinting system.

Figure 2. Commercially available EBB bioprinters: (A) Alpha (courtesy of 3Dynamic Systems Ltd, Swansea, United Kingdom), (B) Omega (courtesy of 3Dynamic Systems LTD, Swansea, United Kingdom), (C) Biobot 1 (courtesy of BioBots, Philadelphia, PA), (D) Inkredible (courtesy of Cellink, Palo Alto, CA), (E) Regemat (courtesy of Regemat 3D, Granada, Spain), (F) 3D Bioplotter (courtesy of EnvisionTEC GmbH, Gladbeck, Germany), (G) Novogen MMX (courtesy of Organovo Holdings INC., San Diego, CA), and (H) nScrypt 3Dn-300TE (courtesy of nScrypt, INC., Orlando, FL).

Figure 3. Commercially available DBB Bioprinters: (A) jetlab®II (courtesy of MicroFab Technologies INC., Plano, TX) and (B) jetlab® 4 (courtesy of MicroFab Technologies INC., Plano, TX).

Figure 4. A Modified low-cost bioprinter: (A) The Solidoodle Workbench Apprentice was modified into an extrusion-based bioprinter (B) with a pneumatic-driven dispensing mechanism and (B) used to bioprint concentric tubes of Pluronic F-127 hydrogel. 


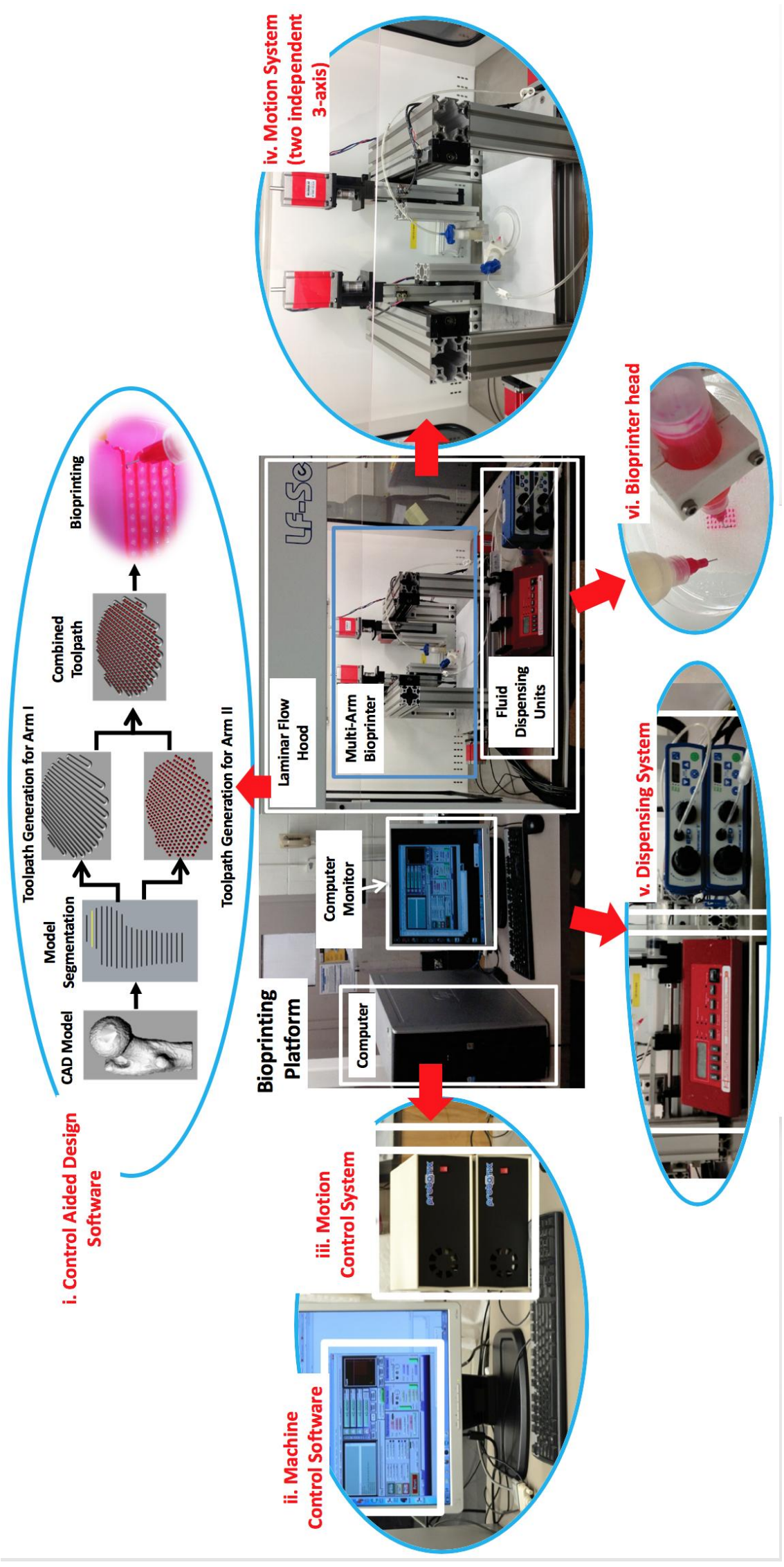



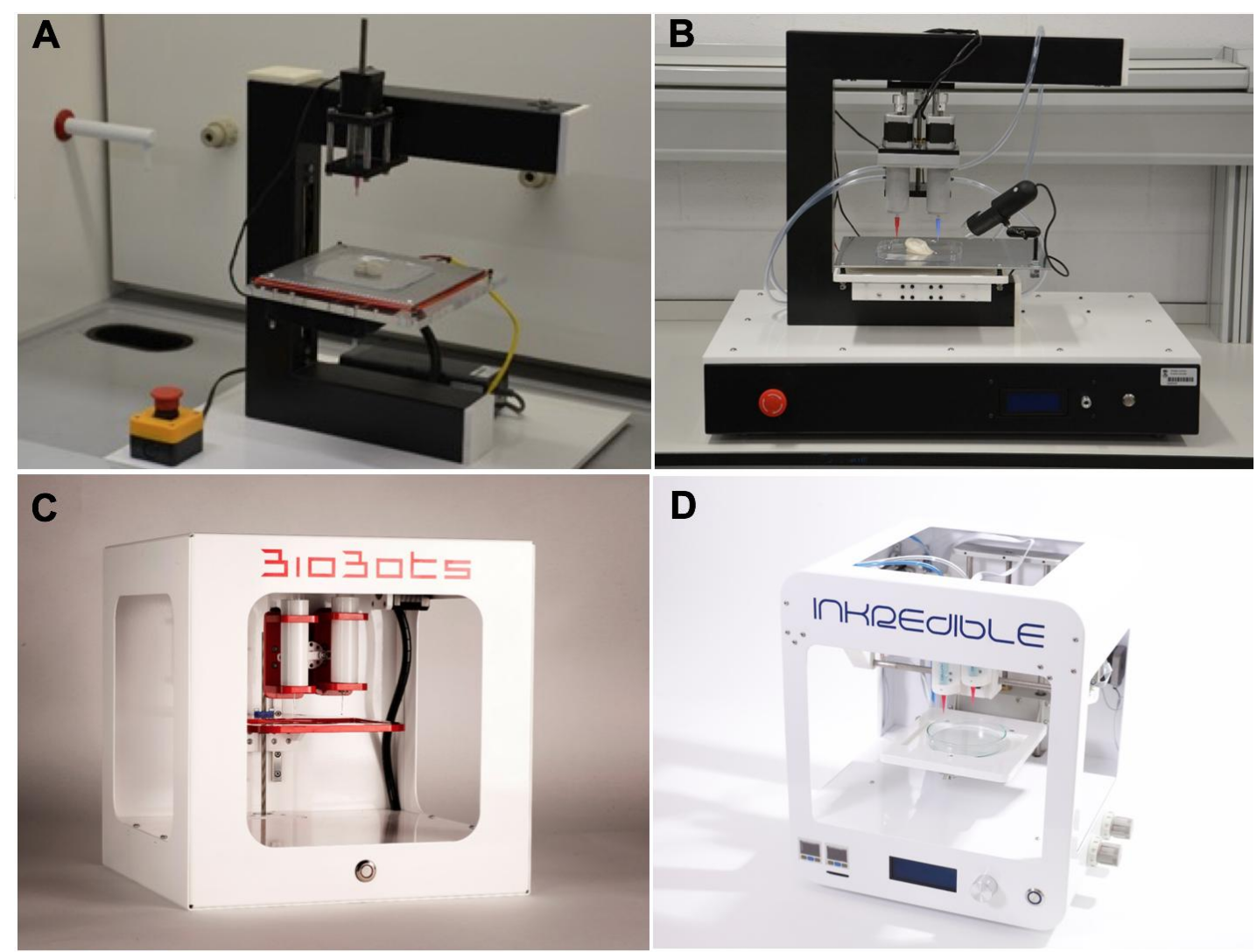

D
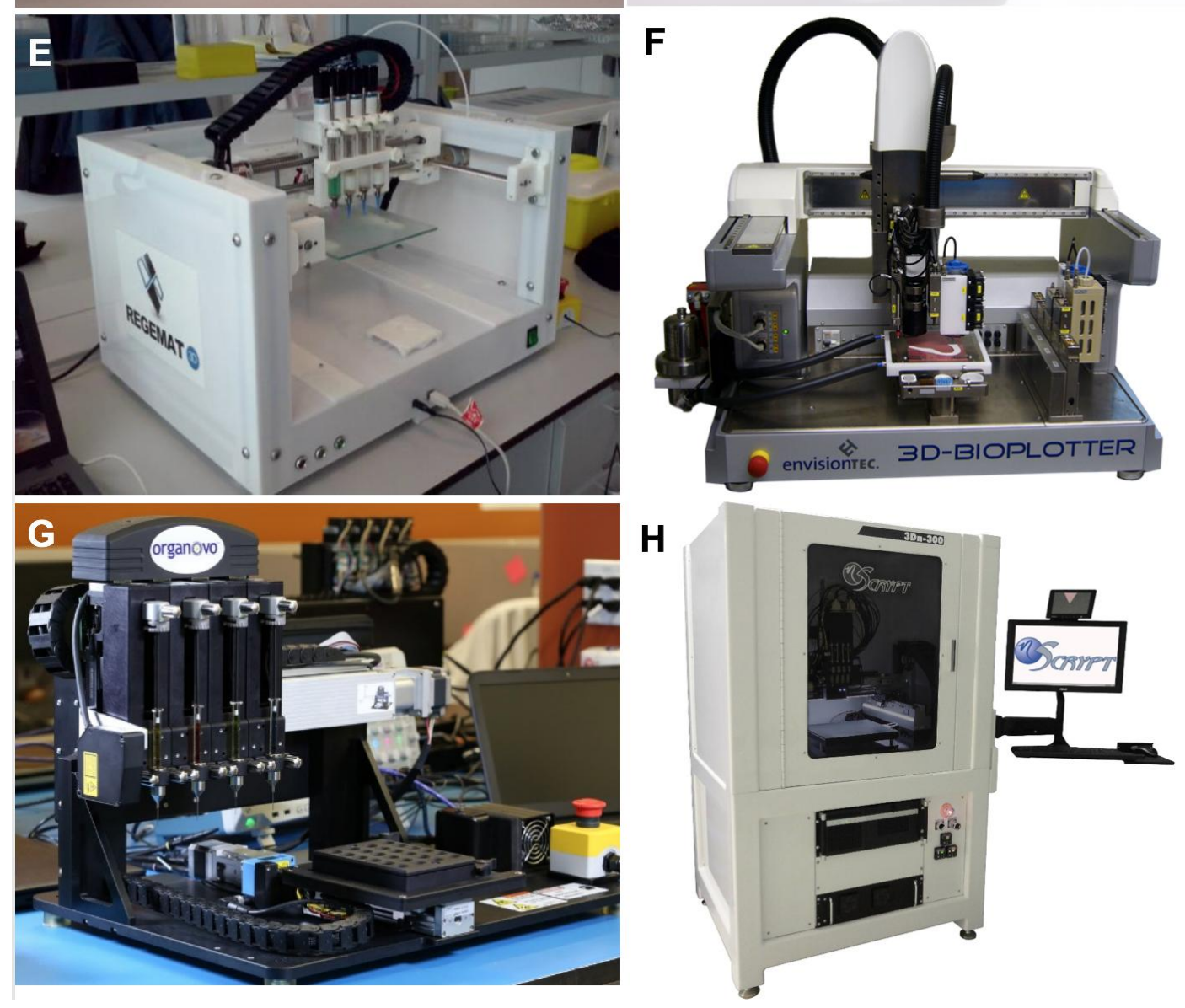
A

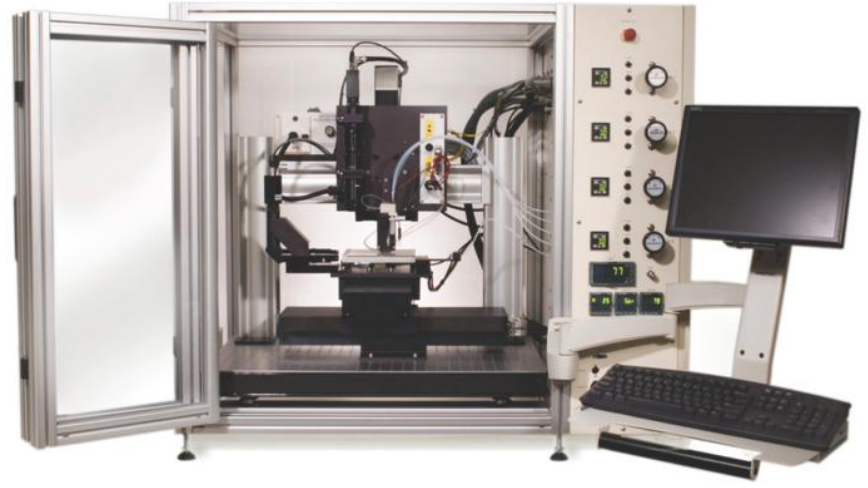

B

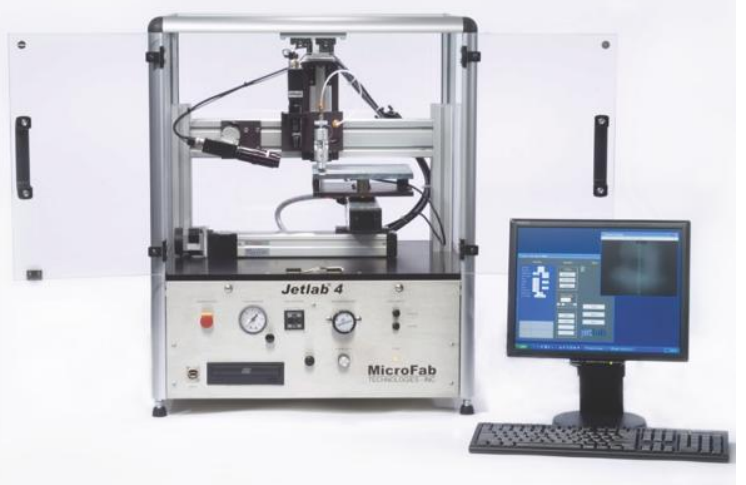



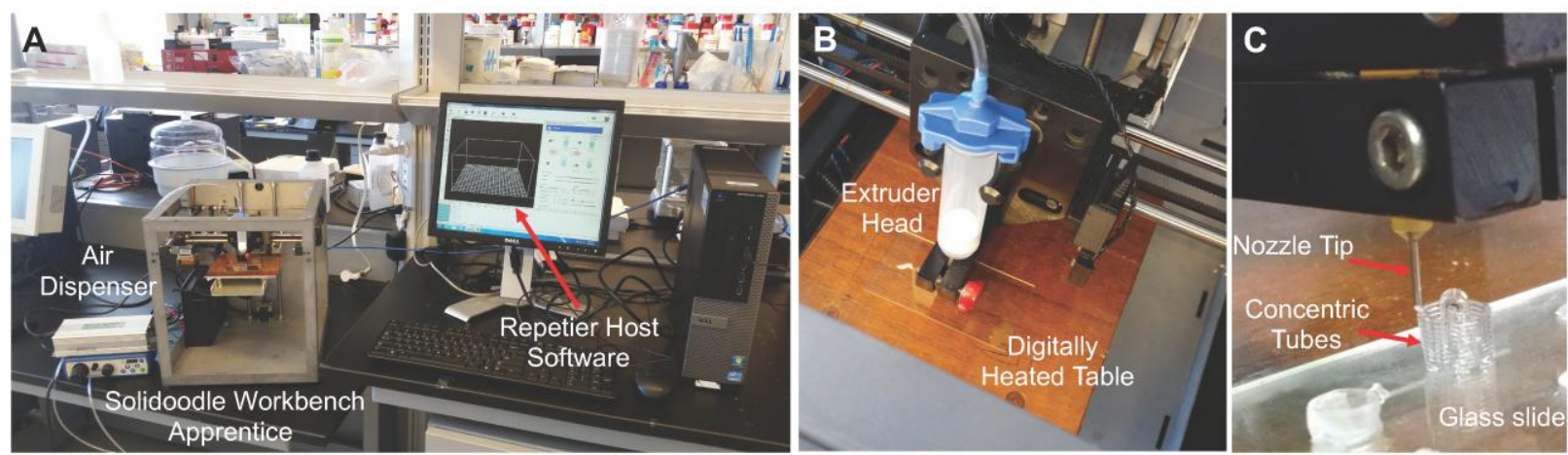